\title{
Governance through Shame and Aspiration: Index Creation and Corporate Behavior in Japan
}

\section{Citation}

Chattopadhyay, Akash, Matthew D. Shaffer, and Charles CY Wang. "Governance through Shame and Aspiration: Index Creation and Corporate Behavior in Japan." Harvard Business School Working Paper, No. 18-010, July 2017

\section{Permanent link}

http://nrs.harvard.edu/urn-3:HUL.InstRepos:33840638

\section{Terms of Use}

This article was downloaded from Harvard University's DASH repository, and is made available under the terms and conditions applicable to Open Access Policy Articles, as set forth at http:// nrs.harvard.edu/urn-3:HUL.InstRepos:dash.current.terms-of-use\#OAP

\section{Share Your Story}

The Harvard community has made this article openly available.

Please share how this access benefits you. Submit a story.

Accessibility 


\section{Governance through Shame and Aspiration: Index Creation and Corporate Behavior in Japan}

Akash Chattopadhyay

Matthew D. Shaffer

Charles C.Y. Wang

Working Paper 18-010 


\title{
Governance through Shame and Aspiration: Index Creation and Corporate Behavior in Japan
}

\author{
Akash Chattopadhyay \\ University of Toronto \\ Matthew D. Shaffer \\ Harvard Business School \\ Charles C.Y. Wang \\ Harvard Business School
}

Working Paper 18-010 


\title{
Governance through Shame and Aspiration: Index Creation and Corporate Behavior in Japan
}

\author{
Akash Chattopadhyay \\ University of Toronto \\ Matthew D. Shaffer \\ Harvard Business School \\ Charles C.Y. Wang* \\ Harvard Business School
}

July 2017

\begin{abstract}
We study how a stock index can affect corporate behavior by serving as a source of prestige. After decades of low corporate profitability in Japan, the JPX-Nikkei400 index was introduced in 2014. The index selected 400 large and liquid firms deemed to be best-performing in terms of profitability annually; membership was considered highly prestigious. We document that index-inclusion incentives led firms to increase return on equity (ROE) proportionally by $35 \%$ on average, through higher margins, efficiency, or shareholder payouts, depending on where firms had "slack," but not through changing investments or accruals. These incentives are driven by the prestige associated with the index rather than capital market benefits. Back-of-envelope estimates suggest that the index accounted for $23 \%$ of the average increase in aggregate annual earnings over our sample period and a $3 \%$ increase in aggregate market capitalization. These findings highlight a novel mechanism through which long-standing corporate behaviors can be transformed.
\end{abstract}

Keywords: JPX-Nikkei 400 index; Corporate governance; Japan; Return on equity; Capital efficiency; Corporate norms

JEL: G34, G38, G41, L51, M14, M52

${ }^{*}$ Chattopadhyay (akash.chattopadhyay@rotman.utoronto.ca) is an Assistant Professor of Accounting at the University of Toronto. Shaffer (mashaffer@hbs.edu) is a doctoral candidate at Harvard Business School. Wang (charles.cy.wang@hbs.edu) is the Glenn and Mary Jane Creamer Associate Professor of Business Administration at Harvard Business School. We thank Alma Cohen, Ian Gow, Jody Grewal, Paul Healy, and Krishna Palepu for helpful suggestions. We also thank Raaj Zutshi for excellent research assistance, and Naoko Jinjo and Nobuo Sato for coordinating interviews in Japan. Comments are welcome. 


\section{Introduction}

The pursuit of prestige and social status are central to human motivation (e.g., Kostritsky, 2013; Posner and Rasmusen, 1999). Some scholars have argued that the allocation of prestige is vital to a properly functioning market economy (Zingales, 2015) and must be central to a complete understanding of economic and corporate behavior (e.g., Williamson, 1963; Hayek, 1967).

Although these propositions imply that prestige could be actively employed as a tool to influence managerial and corporate behavior (Miller and Prentice, 2016), since Jensen and Meckling (1976) the corporate governance literature in economics, finance, and accounting has largely focused on the role of formal contracts and financial incentives. But policy-makers and boards could become more constrained in using these tools in the future, in light of the increasing scrutiny of executive compensation. They may need to become more attentive to other, non-pecuniary, channels to motivate and govern managers, including social prestige.

In this paper, we study how membership in a stock index can serve as a source of prestige that can thereby motivate managers and influence corporate behavior. Specifically, we study the impact of firms' incentives to be included in the JPX-Nikkei 400 (JPX400), a new prestige index designed to select and showcase the 400 top-performing Japanese firms in terms of profitability, capital efficiency, and corporate governance. The index premiered in 2014 as a response to Japanese policymakers' concerns that poor capital efficiency, and a culture of de-prioritizing shareholders, had contributed to Japan's decades of economic stagnation. We find that this index had powerful effects in improving corporate profitability and capital efficiency, as measured by ROE, and that this incentive was primarily due to a concern for prestige.

The JPX400 selects its membership each year using a composite score based on operating 
income, ROE, and market capitalization. We focus on measuring firms' responses in ROE, because this measure is the most heavily weighted determinant, the most directly controllable by managers, and directly related to policymakers' goal of increasing capital efficiency. Firms ranked around the margin of index inclusion are most likely to see their inclusion status change as a function of their performance; thus, we hypothesize that these firms have the strongest incentives from the index. ${ }^{1}$

To study how firms behave as a result of their index-inclusion incentives, we compare the ROE responses of those firms we predict to be most affected versus those less affected by the JPX400. Identifying firms' incentives ideally requires firms' relative ranks in the composite score, which is not published by the Japan Exchange Group. However, since selection for the JPX400 uses a transparent algorithm based on publicly available information, we are able to synthetically replicate these ranks, and show that our synthetic ranks are able to predict actual JPX400 membership with a high degree of accuracy as well as explain the variations in index-inclusion likelihoods across firms.

We employ a difference-in-differences (DID) design using these synthetic ranks, where treated firms are defined as those with synthetic ranks around the inclusion threshold (ranks 301-500 in our main specification) and controls are defined as firms with similar ranks but much smaller probability of gaining inclusion in the index (firms ranked 501-800). Our DID compares the difference in outcomes for these two groups in the post-period (years 2015-2016) relative to their differences in the pre-period (years 2011-2013). ${ }^{2}$ A unique feature here is

\footnotetext{
${ }^{1}$ More formally, assume there is some fixed benefit to being included in the index. Conditional on any effort level, firms close to the margin of inclusion (e.g., firms ranked 401-500) have a higher probability of gaining this benefit than firms ranked further from the margin of inclusion; symmetrically, conditional on any effort level, firms closer to the margin of exclusion (e.g., firms ranked 301-400) have a higher probability of losing this benefit than firms ranked further from the margin of exclusion. Therefore, these firms have a higher expected benefit from exerting effort to be included in the index. For shorthand, we refer to these higher expected benefits as higher "index-inclusion incentives."

${ }^{2}$ We exclude the 2013 selection year, since firms did not have sufficient time to respond in the first year
} 
that, unlike traditional DID designs, a firm's treatment status varies over time: a firm's ranking for JPX400 selection, thus its distance from the index-inclusion threshold, varies year by year. Therefore, our research design in effect combines multiple "experiments" in the post-JPX400 period with multiple placebo "experiments" in the pre-period to infer the effect of JPX400-inclusion incentives.

We document three main empirical findings. First, firms closest to the JPX400-inclusion threshold achieve differential and economically significant increases in ROE. We estimate that these firms improved ROE by $1.8 \%$, a $35 \%$ proportional increase relative to the preperiod mean among the treated firms. A battery of tests supports the hypothesis that this effect is driven by index-inclusion incentives, i.e., the firms' efforts to improve ROE in order to be included in (or avoid exclusion from) the index. In particular, we document that the ROE increases a) do not appear to be driven by differential trends, b) are not due to the realized consequences of being included in the index, and c) are monotonically related to a firm's distance to the threshold of inclusion.

Second, we show that the prestige associated with the index, rather than benefits relating to the cost or availability of capital, is the primary factor motivating treated firms to improve ROE. We show this by comparing the ROE response of Nikkei225 firms - who have high public visibility and thus especially strong "shame" from exclusion from the index, but smaller marginal cost-of-capital benefits - to the ROE response of non-Nikkei225 firmswho would have larger cost-of-capital benefits from index inclusion, but less "shame" from exclusion. ${ }^{3}$ Using a modified DID design and a difference-in-difference-in-differences design,

of the index's implementation. Nevertheless, including this year does not change our results qualitatively. Details of the index and its implementation are described in Section 3 and Figure 1.

${ }^{3}$ The Nikkei225 is Japan's leading stock market index as well as the oldest stock index in Asia. It consists of Japan's most well-respected and prestigious firms across 36 industries, as selected by Japan's top financial publication, Nihon Keizai Shimbun. 
we show that the ROE response is substantially larger among Nikkei225 firms. This is consistent with the hypothesis that the prestige of index inclusion, as opposed to capital market benefits, is the primary factor motivating treated firms to improve their performance.

Third, we show that treated firms improve their ROE by improving margins, asset efficiency, or shareholder payouts, rather than by earnings management or cutting investments. Our findings suggest that treated firms exploit the channels where they have the most "slack" to improve their ROE. Treated firms with below-median profit margins differentially improve their margins; those with below-median asset turnover improve efficiency; and companies with above-median cash-to-equity ratios increase shareholder payouts. However, while the effect sizes for profit margins and asset turnover are economically meaningful, the effect on shareholder payouts is economically small. Additionally, we find that the treated firms' ROE improvements drove higher market valuations.

Overall, our findings suggest that the JPX400 "shame" index was quite successful in leveraging prestige incentives to improve shareholder equity efficiency at Japanese firms. These estimates also imply that, in the aggregate, the JPX400 made a significant contribution to the overall economy. Our back-of-the-envelope estimates suggest the introduction of JPX400 increased the aggregate net income by JPY977.28 billion per year, representing a $6.5 \%$ increase relative to the pre-period average aggregate income of Japanese firms or $23.4 \%$ of the change in average annual aggregate net income from the pre-period to the post-period. Moreover, we estimate that the incremental total earnings attributable to the JPX400 represents a 3\% increase in Japanese market capitalization.

Our findings contribute to the corporate governance literature in two ways. First, we show that prestige incentives - whether the prospective shame from loss of prestige or the aspiration to attain prestige - can powerfully shape how organizations and managers behave. 
We add to a small body of literature showing the importance of prestige incentives to corporate executives (e.g., Avery, Chevalier, and Schaefer, 1998; Raff and Siming, 2017; Focke, Maug, and Niessen-Ruenzi, 2017), offering a fresh perspective to the governance literature that has primarily focused on pecuniary incentives (e.g., Bebchuk and Fried, 2003). Second, we show that, by creating a source of prestige, a stock index can shape these prestige incentives and thereby influence corporate behavior. These insights could inform policy makers as they seek to design non-pecuniary channels of corporate governance, which may be particularly useful in the context of increasing pressures in the U.S. and abroad to limit executive compensation or in developing markets that may face limits to contracting.

Our findings also contribute to the index-inclusion literature. Most prior literature on indexes has examined how index constituents behave and perform in response to being included in an index (e.g., Shleifer, 1986; Harris and Gurel, 1986; Dhillon and Johnson, 1991; Lynch and Mendenhall, 1997; Chen, Noronha, and Singal, 2004; Doh, Howton, Howton, and Siegel, 2009). In contrast, we study how firms behave and perform in order to achieve inclusion in or in order to avoid exclusion from an index. We also develop a novel empirical strategy for estimating the effects of index-inclusion incentives more generally. Our DID research design could be adapted to estimate the effects of other indices that have transparent inclusion criteria using publicly-observable performance measures.

The remainder of the paper proceeds as follows. Section 2 provides background on the literature on prestige and human behavior and on the JPX400 index. Section 3 details our research design and identification strategy. Section 4 describes in detail our empirical analysis. Section 5 discusses the overall effect of the JPX400 and provides back-of-the-envelope estimates on aggregate earnings and market capitalization impacts. Section 6 concludes. 


\section{Background}

\subsection{Governance and Reform in Japan}

In Japan, in the post-war period, managers prioritized the interests of employees, suppliers, customers, and strategic stakeholders over those of shareholders (e.g., Yoshimori, 1995; Ito, 2014). Although shareholders developed strong formal legal rights over the years, Japanese corporate culture assigned low prestige to the pursuit of shareholder value, and more status to the guardianship of other stakeholders' interest, limiting shareholders' de facto power. Even through the early 21st century, shareholders' interests carried less weight and legitimacy with managers, and activists were often unsuccessful convincing even their fellow shareholders to vote for initiatives to boost payouts and efficiency. These norms persisted even despite the country's efforts to improve its formal corporate governance regime (e.g., Allen, Carletti, and Marquez, 2015; Kato, Li, and Skinner, 2017). Many policymakers in Japan cited the country's stakeholder-oriented culture as an important reason for its lagging corporate capital efficiency - its low return-on-equity (ROE) and return on assets (ROA) - and the country's decades of economic stagnation. ${ }^{4}$

Many policymakers came to believe that improving Japanese corporations' capital efficiency, by increasing dialog with and focus on investors, would be vital to reviving the economy, an urgent concern in light of Japan's looming problems. As the Ito (2014) report notes:

"Japan faces a rapidly aging and declining population and a decreasing stock of labor and household financial assets. Japan has no room to waste its limited resources and capital. Japan must effectively leverage the resources... In other

\footnotetext{
${ }^{4}$ For example, Chart 3 of Ito (2014) reports an average ROE of $5.3 \%$ among Japanese firms in the TOPIX500 in 2012, roughly a quarter of the average among the S\&P500 firms in the U.S. and a third of the average among the firms in the Bloomberg European 500.
} 
words, increasing capital efficiency in the broadest sense is crucial from the perspective of Japans survival. Japanese companies - as a critical source of value creation - must strive to increase capital efficiency through their dialogue with investors, and contribute to the accumulation of a broad range of capital stock that will serve as the foundation for future economic prosperity."

These goals and concerns were reflected in the Abe's administration's "third arrow" of structural reforms, a major fraction of which focused on increasing Japanese corporations' accountability to and focus on shareholders.

\subsection{The JPX-Nikkei 400 Index}

In response to these concerns and calls for reform, in 2014, the Japan Exchange Group (JPX) and Nikkei Inc. launched a new prestige stock index, the JPX-Nikkei 400 (JPX400). The JPX selected and showcased the top 400 firms in Japan as ranked on a measure of profitability, capital efficiency, and valuation (subject to meeting certain governance and liquidity criteria; see Section 3 for a full and exact description of the algorithm). Each summer, the JPX re-formed the index membership, booting out firms that no longer made the cut and adding firms that had improved their performance. The index per se offered no direct financial benefits to the constituent firms or their managers, but membership in the index was considered highly prestigious - it became colloquially referred to as the "shame" index, a reference to the experience of firms that were excluded. One major event that bolstered JPX400's prestige status was the Government Pension Investment Fund's (GPIF) decision to use the JPX400 as one of the benchmarks it would track for its passive investments in 2014. ${ }^{5}$ Anecdotal evidence, news media reports, and interviews with top

\footnotetext{
${ }^{5}$ Two other reforms in 2014 were also implemented and designed to encourage manager-shareholder dialogue: the Stewardship Code and the Corporate Governance Code in 2014. The Stewardship Code, issued in February 2014, encouraged institutional investors to pursue long-term returns and engage companies in constructive dialogue. The Corporate Governance Code, a "Bill of Rights" for shareholders, urged companies
} 
managers in Japan all suggested that many managers - both of firms that were initially included and of those that were initially excluded - were motivated to improve their firms' performance. Many excluded firms aspired to gain entry eventually; many included firms feared the shame of eventually being excluded. ${ }^{6}$

We highlight two important features of the JPX's selection criteria. First, the algorithm is explicit, transparent, and, with the exception of a small number of "qualitative adjustments," based off of publicly available financial data. This means that we are able to reconstruct firms' JPX400 ranks, including synthetic (or placebo) ranks for years prior to the existence of the index. As we will discuss in more detail below, the transparency and replicability of the selection algorithm is critical to our research design.

Second, the JPX publishes and tracks the constituents of the index each year; however, it does not publish the constituents' underlying ranks. Consequently, the publicity around the index churn each August focuses on companies' inclusion vs. exclusion status, but never addresses the relative rank of included or excluded companies. This motivates our assumption that companies near the margin of inclusion vs. exclusion have stronger incentives than those with ranks that render them relatively "safe."

While the creation of the index, and its churn each August, have generated substantial excitement and attention in the media, so far we have seen no attempts to systematically estimate the impact of the index. The Japan Exchange Group has been tracking and pub-

to respect shareholder rights, improve capital efficiency, engage investors in dialogue on a regular basis, and appoint at least two external directors to their boards. Neither of these codes, however, are legally binding. Institutional investors and companies subject to the codes are not required to abide by all of their principles; instead, they are required to either comply or explain.

${ }^{6}$ For example, after Amada, a well-established 68-year-old tool-maker and a member of the Nikkei225 index, was excluded from the inaugural JPX400 index in 2014, president Mitsuo Okamoto announced that the company intended to improve its capital efficiency and shareholder returns as well as appoint independent directors in order to gain entry into the prestigious new club. On the other hand, some firms that were included in the index, such as Unicharm, aimed to cement their status among the elite, perhaps in fear of losing such status, by planning to further improve ROE (McLannahan, 2014). 
lishing the returns of the index but, for reasons we discuss in Section 5, this is not the correct way to estimate the effects of the index.

\subsection{The Role of Prestige}

The desire and competition for prestige are important motivators of human behavior. As early as 1966, Nobel laureate John Harsanyi claimed that "[A]part from economic payoffs, social status (social rank) seems to be the most important incentive and motivating force of social behavior," and included status as one of the goods being bargained over in formal game-theoretic models of organizations Harsanyi (1966). Economic theory models agents as having preferences over bundles of diverse goods, and it seems reasonable to assume that social prestige is one of the goods that humans, and perhaps managers especially, desire. For example, in a review of the research on CEOs, Bertrand (2009) claims that people are motivated to work to become CEOs by "the prestige, high social status, and high salaries."

Several scholars in economic fields have argued for the importance of prestige and status, in advancing our understanding of corporate and financial behavior. For example, Elster (1989) argues that norms that are "shared by other people and partly sustained by their approval and disapproval" are stronger determinants of human behavior than the "instrumental rationality" that has been the historical focus of economic theory. More recently, Zingales (2015) frames social prestige as an incentive that emerges via a Hayekian evolutionary mechanism to "fill the gap between (perceived) social and private returns of various activities. For example, fighting the spread of Ebola is an activity with a very high social return, but a very low private return. People who engage in such activity are held in high regard by society." In other words, cultures assign high status to - and thereby incentivize people to undertake - activities that generate benefits for society that cannot be internalized, 
monetized, and/or fully contracted around. Prestige thus becomes a motivator of behavior that is traded off with those goods.

Nonetheless, economic approaches to incentive contracting and corporate governance have tended to focus on the formal, monetary incentives of managers - this could be because these incentives are easier to measure and model, and because in many settings it is difficult to tease out the separate influences of managers' desires for wealth vs. social status, since the two often move together. For example, "empire building" by managers is sometimes assumed to be a classic case in which managers pursue the nonpecuniary desire to run a large, prestigious firm (increasing their probability of being included in the Fortune 500, etc.), but it is also sometimes assumed that "empire building" could be driven by pecuniary incentives, under the assumption that firm size drives CEO pay. The empirical literature has found mixed results across different time periods and geographies. For example, Disney, Bridges, Gathergood, Disney, Bridges, and Gathergoodj (2006) find that, in their setting (the U.K. from 1981 to 1996), acquisitions increase CEO pay despite reducing shareholder

wealth. In contrast, Avery et al. (1998) find that acquiring CEOs do not have significantly different compensation growth from their matched non-acquiring peers, which they interpret as evidence that acquisitiveness is driven by the desire for prestige and status.

\subsection{Prestige in Corporate Japan}

Both anecdotal evidence and research by Japanese scholars suggests that nonpecuniary factors such as social status and prestige are important in the Japanese corporate environment. For example, Aoki, Jackson, and Miyajima (2007) note that CEOs in Japan are overwhelmingly internally promoted, and argue that they are thus perceived as, and act as, the "top employees" of the firm, rather than as agents of shareholders. The authors charac- 
terize the Japanese corporate environment as one that is more "relational," i.e. focused on long-term relationships and reputation. Today's Japanese corporate culture emerged in the post-war period of government-led reconstruction and industrial policy; even into the 21st century, there remained close coordination between Japanese corporations and the government and ministries, and managers saw themselves as guardians of a collective "corporate value," (rather than shareholder value) Aoki et al. (2007). In 2014, Japanese managers rated shareholders as their fourth most important stakeholders, behind customers, employees, and suppliers. ${ }^{7}$ Perhaps even more starkly, not just managers but also shareholders in Japan may be focused on non-pecuniary desiderata. One salient example of this comes from the experience of activist shareholders in Japan in the early 2000s. As Buchanan, Chai, and Deakin (2013) document, activist shareholders were frequently able to get open shareholder votes on proposals that cash-rich Japanese firms increase their payouts, and faced no formal structural barriers (such as from corporate charters, classified shareholders, or Japanese courts), but their proposals were simply voted down by Japanese retail investors who chose to remain loyal to their companies' management.

As such, we assume that social prestige and status are important determinants of managerial behavior in Japan, and we interpret the JPX400 index as an attempt to influence corporate behavior primarily through these mechanisms. Anecdotal evidence, news media reports, and interviews with Japanese managers and investors all suggest that managers consider it to be prestigious to be included in the index, and shameful to be excluded.

Bringing these strands together, we frame the JPX400 index as an attempt to influence Japanese corporate behavior by assigning social prestige to inclusion in an index that is based on performance measures of interest to policymakers and shareholders. This was motivated

\footnotetext{
7 "Change for the Better: Corporate Governance in Japan," Schroders TalkingPoint, April 22, 2014, Figure 1, accessed December 5, 2014.
} 
by Japanese policymakers' belief that improved competitiveness and capital efficiency would help revive the Japanese economy. In the Zingales (2015) framework, the JPX400 represents Japanese policymakers' attempt to allocate social prestige to direct corporate behavior toward socially beneficial ends.

\section{Empirical Design}

We study how the index-inclusion incentives created by the JPX400 affect firm performance. Firms closer to the threshold of index inclusion are the most likely to see their inclusion status change as a function of their performance. Thus, we hypothesize that, all else equal, firms closer to the threshold of index inclusion differentially improve ROE, the aspect of performance most controllable by managers in affecting the index-inclusion outcome. Moreover, we hypothesize that such an incentive might operate through managers' concerns for prestige - either due to the threat of loss of prestige (shame) or the desire to gain prestige (aspiration).

To test these hypotheses requires us to measure firms' index-inclusion incentives ex ante. Our maintained assumption is that, although the JPX does not publish its rankings of firms, managers (at least approximately) understand their relative rankings for the purposes of index inclusion and are aware of how close their firm are to the threshold of index inclusion due to the transparency of the JPX400's selection algorithm.

Thus, our empirical strategy is anchored on a synthetic replication of the JPX400's selection rankings of eligible firms. We validate these synthetic ranks, then use them as a basis of a difference-in-differences design to infer how index-inclusion incentives affect firms' ROE. Each of these steps is detailed in the following subsections. 


\subsection{Synthetic JPX400 Ranks and Sample Construction}

We obtain Worldscope data on annual fundamentals (including but not limited to all the underlying variables listed in Table A1), as well as Datastream data on monthly prices, volume, outstanding shares, and returns, for a comprehensive list of Japanese securities tracked by Datastream from 1990 to $2016 .^{8}$ We drop those observations that are missing returns, have an empty "data date" field for fundamentals data, or are duplicated on their Datastream identifier and relevant time indicator. We also merge in an indicator for Nikkei225 membership, constructed using historical constituents updates archived on the Nikkei website. ${ }^{9}$

We then replicate the algorithm followed by the Japan Exchange Group for constructing the JPX400 index, and use the resultant synthetic ranks as the basis for designing our empirical analyses. ${ }^{10}$ As illustrated in Figure 1, the JPX selects a new vintage of JPX400 members on the last day of June each year, using price and volume data available up to that time and financial-statement data released prior to April. ${ }^{11}$ We match this timing, and use the same information used by the JPX each June in constructing our own synthetic rank.

The JPX400 selection algorithm begins by filtering TSE-listed companies on several criteria. First, it excludes all companies that (1) have been listed fewer than three years on

\footnotetext{
${ }^{8}$ Although selection of firms for the JPX400 was initiated in 2013, we collect data as far back as 1990 in order to perform placebo tests described in detail below.

${ }^{9}$ The set of current constituents and historical changes can be obtained at https://indexes.nikkei. co.jp/en/nkave/index/component. We first construct an annual dataset consisting of all the Nikkei225 firms in each year, then match these firms to our baseline sample using their four-digit tickers (Datastream's "Local Offering Code"). We code firms' Nikkei225 indicators as equal to 1 in each year if they were Nikkei members on the date on which the JPX400 index for that year was announced. We achieve a complete match for Nikkei225 members in all years.

${ }^{10}$ The JPX400 selection algorithm and other important dates are described in the JPX-Nikkei Index 400 Guidebook, available at http://www.jpx.co.jp/english/markets/indices/jpx-nikkei400/.

${ }^{11}$ As shown in Figure 1, the inaugural year was an exception to this rule. As we explain below, our empirical design excludes the first year (2013) of index selection.
} 
the TSE, (2) have had negative book value in any of the past three years, (3) have had negative operating income in all of the past three years, or (4) are in the process of being de-listed. ${ }^{12}$ From this pool of eligible firms, the JPX then selects the top 1,200 stocks by "trading value" (price times volume, or the total value of transactions in the stock over the past year). Finally, of these 1,200 stocks, the JPX filters down to the top 1,000 stocks by market capitalization.

These 1,000 firms, which we refer to as the "ranked set," are then ranked based on the following composite score (Total_Score):

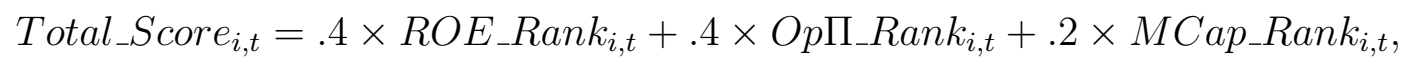

where $R O E_{-} R_{a n k},{ }_{i, t}, O p \prod_{-} R a n k_{i, t}$, and $M C a p_{-} R a n k_{i, t}$ are firm $i$ 's rank in the ranked set in terms of 3-year average ROE, 3-year total operating profit, and market capitalization, respectively.

The index constituents each year are chosen based on the 400 firms with the highest Total_Score, but with one caveat: the JPX reserves the right to make up to 10 "qualitative adjustments" per year based on corporate governance and disclosure-related factors. These qualitative adjustments are not determined by factors that we can observe, but according to our our interview with representatives of Japan Exchange Group (as well as the empirical evidence presented in the next subsection), they are insignificant. For our research purposes, we treat these "qualitative adjustments" as random noise in the index-inclusion rule. We follow the JPX400 selection algorithm precisely, with the exception of the qualitative adjustments, and create synthetic JPX400 ranks for each year from 1994-2016.

\footnotetext{
${ }^{12}$ We refer to TSE-listed companies as those listed on the First, Second, and Mothers Section of the Tokyo Stock Exchange as well as those listed on the JASDAQ.
} 


\subsection{Research Design}

We utilize these synthetic ranks to test how index-inclusion incentives affect firm behavior. Our main dependent variable of interest is ROE. Of the three components of the indexselection score (equation 1), ROE is the only scaled variable and thus its ranking is the most controllable by managers. The other two components, market capitalization and operating income, are unscaled and thus their variations are largely driven by firm size. Although managers may be able to increase firm size through seasoned equity offerings or acquisitions, these channels would likely generate a competing effect on a firm's rankings for the JPX400 by increasing the equity base and, ceteris paribus, decreasing ROE. Thus, we expect to observe the incentive effects of the JPX400 most cleanly in ROE.

Our main tests compare the ROE of those firms close to the threshold of JPX400 inclusion - those with a synthetic rank of 301-500 - to the ROE of those firms outside of the threshold of inclusion - those with a synthetic rank of 501-800. We make this comparison in 2014 and 2015, and exclude 2013, because the JPX400's inaugural constituents were announced at the end of 2013, affording firms only three months to respond to any indexinclusion incentives. Furthermore, to assess the index-inclusion effect in ROE, we benchmark this first difference against a baseline difference between firms with a synthetic rank of 301500 versus those firms with a synthetic rank of 501-800 prior to the introduction of the JPX400 (in the years 2010-2012). This second difference accounts for the possibility that the treatment assignment, based on the largely deterministic JPX400 selection mechanism, could be associated with baseline differences in ROE or other determinants of rank. Unlike traditional DID designs, a firm's treatment status in our setting varies over time: a firm's ranking for JPX400 selection, thus its distance from the index-inclusion threshold, varies

year by year. Therefore, our research design in effect combines multiple "experiments" in 
the post-JPX400 period with multiple placebo "experiments" in the pre-period to infer the effect of JPX400-inclusion incentives.

Together, our basic research design is summarized in the following differences-in-differences (DID) specification:

$$
\operatorname{ROE}_{i, t+1}=\alpha+\beta_{1} \text { Treat }_{i, t} \times \text { Post }_{t}+\beta_{2} \text { Treat }_{i, t}+\gamma X_{i, t}+f_{t}+\epsilon_{i, t},
$$

where Treat $_{i, t}$ is an indicator equaling 1 for firms ranked 301-500 and 0 for firms ranked 501-800 in a given selection year $t$ under our synthetic reconstruction of the JPX400 ranks; $R O E_{i, t+1}$ is a firm's return on equity in the following fiscal year; Post $t_{t}$ is an indicator for the period after the introduction of the inaugural JPX400 constituents, equaling 1 for years 2014-2015 and 0 for years 2010-2012; $X_{i, t}$ is a vector of contemporaneous firm controls; and $f_{t}$ represents time fixed effects.

The main coefficient of interest, $\beta_{1}$, captures the mean ROE differences between the treatment and control firms in the post-JPX400 period relative to the differences between placebo treatment and control firms in the pre-JPX400 period. Our identifying assumption is that any baseline differences in future ROE - that is, in the absence of JPX400-inclusion incentives - between those firms around the inclusion threshold (treated) and those firms further from the threshold (controls), if they exist, are stable over time, and thus accounted for by the pre-period differences between the placebo treatment and control firms.

We believe that this assumption is most defensible when conditioned on contemporaneous ROE, an important predictor of future ROE, since it is possible that the distribution of contemporaneous ROE changes after the introduction of the JPX400. Thus, our most robust specification - the specification on which we rely the most throughout our empirical 
analysis - includes contemporaneous ROE (or the lagged dependent variable more generally) as a control. Another way to interpret this specification is that its DID estimate $\left(\beta_{1}\right)$ identifies the mean differences in firm-level changes in ROE between the treatment and control firms in the post-JPX400 period relative to the mean differences between placebo treatment and control firms in the pre-JPX400 period.

Finally, we note that the DID coefficients produced by this research design represent a conservative estimate of the JPX400-inclusion incentive effect for the treated group of firms. This is because our research design uses as controls those firms who are less influenced by index-inclusion incentives (ranked 501-800) — effectively assuming that they are unaffected by those incentives. To the extent that these firms do respond to some degree to the incentives of JPX400, our DID estimates would be a downward biased.

\subsection{Validation of Synthetic Ranks}

Our research design relies on a synthetic replication of the JPX400 ranks, which is necessary because, although the JPX publishes the index constituents, it does not publish the underlying rankings. Thus, we begin by empirically validating our synthetic ranks and test whether their variations are meaningfully associated with the probability of JPX400 inclusion (and thus the true ranks). We estimate the following OLS regression:

$$
\text { Actual_Inclusion }_{i, t}=\alpha+\beta \text { Predicted_Inclusion }{ }_{i, t}+\gamma X_{i, t}+\epsilon_{i, t},
$$

${\text { where } \text { Actual_Inclusion }_{i, t} \text { is an indicator for actual JPX400 membership, Predicted_Inclusion }}_{i, t}$ is an indicator taking on the value of 1 for all firm-year observations for which our synthetic JPX400 rank is less than or equal to 400 and zero otherwise, and $X_{i, t}$ is a vector of contem- 
poraneous firm-level controls. To ensure that our analysis of prediction accuracy includes all false negatives, the regression sample includes all firms with synthetic ranks from 1-2000 (based on the top 2,000 firms in terms of trading value) for the selection years 2013-2015.

Columns 1 and 2 of Table 1 report the results of this analysis, with firm-level controls incrementally introduced in column 2 . Column 1 shows that, unconditionally, having a synthetic rank less than or equal to 400 is associated with a $92 \%$ probability of index inclusion. Column 2 adds firm-level controls to assess the extent to which prediction errors, for example those due to "qualitative adjustments," are systematically correlated with firms' fundamentals. We find that Log Market Cap exhibits a significant relationship with the likelihood of JPX400 inclusion, while no other firm attribute-Book to Market, Sales Growth, LT Debt to Equity, and Cash to Equity - does. Since the JPX400 is weighted towards large firms, the positive association between firm size and inclusion likelihood is likely due to the small number of false negatives being on average much larger in size relative to the full sample of 2,000 firms.

Columns 3 and 4 report results of similar analyses, but instead of Predicted_Inclusion, they use indicators of synthetic rank ranges - ranked 1-200, 201-400, 401-600, and outside of 800 - as the main predictors of interest. These tests represent a more granular assessment for whether the variation in the synthetic rank is meaningfully associated with JPX400 inclusion likelihood. Because the quintile indicators are exhaustive, these specifications are estimated without a separate intercept term.

The results of columns 3 and 4 show that the probability of JPX400 inclusion decreases monotonically with our synthetic ranks. Interpreting the coefficients of column 3, we find that, unconditionally, firms we ranked 1-200 have a 99.3\% likelihood of inclusion, and firms we ranked 201-400 have an $87.7 \%$ likelihood of inclusion. On the other hand, lower-ranked firms 
have low inclusion likelihoods: for example, firms we ranked 601-800 have a 0\% likelihood of inclusion. Again, because our synthetic ranks produce a small number of false negatives, we find a statistically significant but economically small likelihood (0.5\%) of index inclusion for those firms we ranked above 800. The results reported in column 4, which now include firm fundamentals as additional controls, are virtually identical to those of column 3. Similar to column 2, the only firm characteristic with a significant association with the likelihood of inclusion is firm size, due to false negative firms being on average larger.

Together, these results show that our reconstructed synthetic JPX400 ranks possess a high degree of validity. These ranks cannot be improved upon by additional controls other than size, suggesting our prediction errors are unlikely to cause systematic biases in our main results.

\subsection{Summary Statistics}

Table 2 reports summary statistics for the sample of firms used for our main analyses (firms with a synthetic rank of 301-800) for the pre-period. The first five columns report the distributional statistics (quartiles, mean, and standard deviation) of covariates for the full sample; and the last three columns report the means for the treatment (ranked 301-500) and control (ranked 501-800) group of firms as well as the $t$-statistics of their differences. Definitions of covariates are detailed in Table A1.

Notably, our treated and non-treated firms differ in their means on several variables related to profitability and size, such as ROA, Asset Turnover, Log NOA, and Log Market Cap. This is expected since the treatment firms are ranked higher than the control firms, and the synthetic ranks are driven by size and profitability. These differences motivate our inclusion of linear controls for firm characteristics. 
Note that although we could have chosen to include firms ranked 1-300 and/or firms ranked 801-1,000 as part of our control group, we find in untabulated tests that doing so accentuates the degree of covariate imbalance. Thus, our design combines a pre-estimation matching of similar firms, matching treatment firms to control firms ranked 501-800, with linear controls to account for local differences.

\section{Empirical Analysis}

This section presents the empirical tests of our hypotheses around the effects of the JPX400 on corporate behavior.

\subsection{JPX400 Inclusion Threshold and Future ROE}

We first test the hypothesis that firms closer to the threshold of JPX400 inclusion are more likely to improve their ROE by estimating equation (2). Table 3 reports estimation results for various specifications of our main DID regression, which compares the forward ROE of firms around the threshold of inclusion, the treated group of firms ranked 301-500, to that of firms under the threshold of inclusion, the control group of firms ranked 501-800.

Column 1 estimates a basic DID specification, without time fixed effects and without any other controls. The DID estimate - the coefficient on Treat $\times$ Post - of 0.021 is statistically significant at the $5 \%$ level, and suggests that those treated firms experienced a 2.1 percentage point higher ROE relative to the control firms. This is an economically significant difference - a $35 \%$ increase in ROE relative to the pre-period treatment-group mean ROE of $5.96 \%$.

Also notable is the positive and significant (at the $1 \%$ level) coefficient on Post. The 
point estimate of 0.019 implies that those firms assigned to the control group had a 1.9 percentage point higher ROE in the post period, or a $37 \%$ increase relative to the pre-period control-group mean of $5.19 \%$. In the context of this economically significant Post coefficient, the DID estimate can be interpreted in two ways. On one extreme, we can attribute all of the secular trend to the effects of the other contemporaneous governance reforms, for example the Corporate Governance Code and the Stewardship Code. If so, our DID estimates suggests that the effect on ROE of being close to the index-inclusion threshold is at least as large as the effects of these other reforms. On the other hand, to the extent that part of the Post coefficient reflects the effects of the JPX400-inclusion incentives on the firms ranked 501-800, our DID coefficient would be downward biased.

Columns 2-4 present estimates from increasingly general and robust DID specifications relative to column 1. Column 2 replaces the Post indicator with time-fixed effects; column 3 adds industry-fixed effects and linear controls for firm attributes that can can also explain ROE, specifically Log Market Cap, Book to Market, Sales Growth, LT Debt to Equity, and Cash to Equity; and column 4 includes contemporaneous ROE as an additional firm-level control. Most notably, the coefficient on Treat $\times$ Post remains similar in size and statistical significance, while the adjusted $R^{2}$ of the regression increases from $2.34 \%$ in columns 2 to 39.01\% in column 4, mitigating concerns about omitted variable biases (Oster, 2017).

As we explain in Section 2, our identifying assumption is that any baseline differences in future ROE between the treated and control firms are stable over time. We conduct two tests of this assumption. Our first test assesses whether there is evidence that the ROE differences between the two groups are changing in the pre-period. Column 5 reports a specification that augments the specification of column 4 with the following additional interaction variables: Treat $_{i, t} \times$ Year $_{2011}$ and Treat $_{i, t} \times$ Year $_{2012}$, where Treat $_{i, t}$ is defined as 
in equation 2, and $Y e a r_{2011}$ and Year $_{2012}$ are indicators for the selection years of 2011 and 2012. These interaction coefficients are insignificant both economically and statistically (at the $10 \%$ level), meaning that relative to the baseline of 2010 , the differences between treated and control firms are not different in 2011 or 2012.

We conduct a second, and more expansive, set of tests based on placebo test regressions going back to 1994. Figure 3 graphs the results of five placebo DID estimates, in which we implement our main regression specification (column 4 of Table 3) for five sets of 6-year sample periods prior to the introduction of the JPX400. In each year, we rank firms based on the JPX400 selection algorithm and the composite score of equation (1), and create placebo treatment and control indicators as in our main tests. Following the precise setup of our main empirical tests, we take 6-year samples, using year four as the post-period indicator, drop year 4 from the analysis, and define the last two years of the sample as the post period, then estimate the DID specification of column 4 of Table 3. Under our identifying assumption, we expect to find placebo DID's that are statistically no different from 0 . Indeed, Figure 3 shows that in none of our placebo DID estimates are statistically different from 0 , providing further support for our identifying assumption.

\subsection{Establishing Index-Inclusion Incentives}

The results of Table 3 suggest that those firms around the the threshold of JPX400inclusion significantly increase ROE. Although these findings could be consistent with managers improving ROE in the hopes of gaining or maintaining index membership, they can also reflect the ex post consequences or benefits of being in the index or could reflect some omitted incentives that happen to be correlated with the JPX400 ranks.

We run a series of tests to show that our findings are explained by ex ante JPX400- 
inclusion incentives. Table 4 reports the results of various tests based on the baseline specification of equation 2, but employ alternate definitions for treatment and control groups firms, different samples, or alternative measurements of treatment intensity.

We first test for the possibility that the ROE effects are due to consequences or benefits of being in the index. Column 1, Table 4 reports the estimates from a specification that splits our treatment indicator into two separate indicators: one for firms which are included in the index, i.e., firms with ranks between 301-400, and one for firms which just missed being included in the index, i.e., firms with ranks between 401-500. If benefits of being in the index explained our results, we would expect to see a stronger coefficient on those treated firms ranked 301-400. However, we find that the estimated DID coefficients for the two separate indicators are nearly identical to each other-0.019 for those ranked 301-400 and 0.018 for those ranked 401-500 - as well as to our baseline DID estimates of Table 3. Both coefficients are statistically significant at the $5 \%$ level and are not statistically different from each other, consistent with the ROE improvements being driven by firms' incentives to be included in the index.

Column 2, Table 4 provides the results of an alternative test, in which we also include those firms ranked 1-300 as placebo treatments. If our ROE effects are driven by ex post index-membership benefits, we would expect to see a coefficient on Rank 1-300 $\times$ Post that is similar in sign and magnitude to the coefficient on Treat $\times$ Post. However, we find that the coefficient on Rank $1-300 \times$ Post is (1) economically small at 0.006, (2) statistically no different from zero at the $10 \%$ level, and (3) statistically different, at the $5 \%$ level, from the coefficient on Treat $\times$ Post, which remains at 0.019. Thus, firms ranked between 1300 exhibit no differential response in Forward ROE as compared to firms ranked 501-800, consistent with firms facing stronger incentives to improve ROE when they are closer to the 
threshold of index inclusion.

The results of column 2 also help to rule out the possibility that our results could be driven by unobserved factors that could be a function of firms' JPX400 ranks. If so, we might expect the coefficient on Rank 1-300 $\times$ Post to be large and significant. We provide a further test for this alternative by conducting the following cross-sectional placebo test. Since the JPX400 selection algorithm filters by the top 1,000 firms in Japan by market capitalization and liquidity, we use the next 1,000 firms - specifically firms ranked 1,001 to 2,000 by market capitalization - and rank them according to equation 1 and re-run our main test. If some omitted factor associated with the algorithm's rank-ordering were driving our results, we would expect the effect to appear in this placebo sample of smaller firms. However, the estimated coefficient on Placebo Group Treat $\times$ Post in column 3 indicates no such evidence, consistent with the findings of column 2. Together, we conclude it is unlikely that some omitted factor correlated with JPX400 ranks could confound our results.

We provide a final test to show that the ROE effects we document are attributable to firms' desires to preserve or obtain JPX400 membership. Because firms closer to the threshold of index inclusion are the most likely to see their inclusion status change as a function of their performance, index-inclusion incentive effects on ROE should be monotonically increasing in a firms' closeness to the threshold of inclusion. To capture the variation in treatment intensity, we sort the 1,000 "ranked set" firms into five quintiles based off of the absolute value of the distance of their rank from the rank-400 cutoff. The resultant variable, Quintile Closeness, ranges from 0 to 4 and is increasing in proximity to the JPX400 cutoff: higher values represent more intense index-inclusion incentives.

Column 5 reports the results of our estimates using the entire ranked set and using this alternative treatment measure. We find a positive and significant (at the $1 \%$ level) on 
Quintile Closeness $\times$ Post. Together with the results of columns 1-4, these findings suggest that the observed effects on ROE are likely driven by firms' desire to be included in the index.

\subsection{Incentive Channel: "Prestige" vs. Capital Market Benefits}

We now turn to understand why firms wanted to be part of the JPX400 index. Our hypothesis is that firms coveted membership in the index due to prestige - the aspiration to acquire prestige or the (potential) shame from loss of prestige. This is possible in light of the perceived prestige of JPX400's membership and its colloquial label - the "shame" index. However, it is also possible that firms aimed to be part of the index due to factors relating to capital market benefits, such as greater liquidity or lower cost of capital, which could be expected given that the GPIF promised to track the index and other institutional investors could be expected to follow suit.

To understand which of these two candidate explanations are more likely to explain our findings, we exploit cross-sectional variation in the treatment response between Nikkei225 and non-Nikkei225 firms. Nikkei225 is Japan's leading stock index and is highly tracked by institutional investors; it consists of Japan's largest, most liquid, and well-established firms across 36 industries. As a result, these firms are likely to have lower incremental capital market benefits from inclusion in an additional stock index relative to non-Nikkei225 firms. On the other hand, since Nikkei225 firms are large, prestigious, and prominent, these firms are more likely to be sensitive to prestige incentives, such as the "shame" of being excluded. Thus, under our prestige incentives hypothesis, we would expect to observe a larger ROE response for the Nikkei225 firms relative to the non-Nikkei225.

We test the prestige incentive hypothesis empirically in two ways. First, we employ 
our main DID specifications but split our treatment group indicator into Nikkei225 and non-Nikkei225 subgroups. Such a specification allows for treatment-differences between Nikkei225 and non-Nikkei225 firms, but assumes that there are no Nikkei225 and nonNikkei225 specific effects. That is, it does not allow the controls to differ based on Nikkei225 status.

Column 1, Table 5 re-runs our main specification (column 4 in Table 3), but splits the treatment indicator into the two subgroups. It reports estimates from the following equation:

$$
\begin{aligned}
& \text { ROE }_{i, t+1}=\alpha+\beta_{1} \text { Treat }_{i, t} \times \text { Nikkei225 }_{i, t} \times \text { Post }_{t}
\end{aligned}
$$

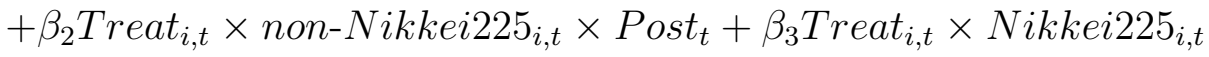

$$
\begin{aligned}
& +\beta_{4} \text { Treat }_{i, t} \times \text { non-Nikkei22 } 5_{i, t}+\gamma X_{i, t}+f_{t}+\epsilon_{i, t} .
\end{aligned}
$$

With the exception of the Nikkei225 and non-Nikkei225 indicators, all other variables are described as in equation 2. We find that the estimated coefficient of 0.050 on Treat $\times$ Nikkei225 $\times$ Post is almost four times that of 0.013 on Treat $\times$ non-Nikkei225 $\times$ Post (a difference that is statistically significant at the $5 \%$ level), consistent with prestige incentives being the primary driver of the ROE effects. Column 2 repeats this exercise, but replacing the binary treatment indicator with the Quintile(Closeness) treatment measure used in Table 4. Again, the estimated treatment response for Nikkei225 firms is larger in magnitude - twice as large - and is statistically different from that for non-Nikkei225 firms.

To complement these tests of the prestige incentive hypothesis, we compare the DID in ROE among the subset of Nikkei225 firms against the DID in ROE among the subset of non-Nikkei225 firms by employing a difference-in-difference-in-differences (DDD) design. This test is more general than those in columns 1 and 2 because it relaxes the restriction of 
no Nikkei225 and non-Nikkei225 specific effects; however, it comes at the cost of precision.

Column 3, Table 5 reports coefficient estimates from the following DDD equation:

$$
\begin{aligned}
& \text { ROE }_{i, t+1}=\alpha+\beta_{1} \text { Treat }_{i, t} \times \text { Nikkei225 }_{i, t} \times \text { Post }_{t}+\beta_{2} \text { Nikkei22 }_{i, t} \times \text { Post }_{t} \\
& +\beta_{3} \text { Treat }_{i, t} \times \text { Post }_{t}+\beta_{4} \text { Nikkei225 }_{i, t}+\beta_{5} \text { Treat }_{i, t}+\gamma X_{i, t}+f_{t}+\epsilon_{i, t} .
\end{aligned}
$$

We report a coefficient of 0.034 on Treat $\times$ Nikkei22 $5 \times$ Post, the DDD estimate, which is

both economically and statistically significant. Although there is a loss of precision in this coefficient estimate, as expected, it remains significant at the $10 \%$ level. The point estimate indicates that the treatment response for the Nikkei225 firms is more than 3 percentage points higher than that of the non-Nikkei225 firms; moreover, these results suggest that the DID estimate among Nikkei225 firms is statistically different from the DID estimate among non-Nikkei225 firms at the 10\% level. Column 4 repeats this exercise, but replacing the binary treatment indicator with the Quintile(Closeness) treatment measure used in Table 4. We find a positive and significant (at the $10 \%$ level) coefficient on Quintile(Closeness) $\times$ Nikkei225 $\times$ Post, providing further evidence of a stronger treatment response for Nikkei225 firms. Collectively, these results suggest that the dominant incentive channel driving the ROE effect we document is prestige rather than the capital market benefits associated with index inclusion.

\subsection{Drivers of the ROE response}

Next, we study which levers managers pull to generate the improvement in ROE that we document. We use a simple DuPont decomposition, which decomposes ROE into ROA and 
asset leverage, and further decomposes ROA into net profit margin and asset turnover:

$$
\begin{aligned}
R O E=\frac{\text { NetIncome }}{\text { Equity }} & =\underbrace{\frac{\text { NetIncome }}{\text { Assets }}}_{\text {ROA }} \times \underbrace{\frac{\text { Assets }}{\text { Equity }}}_{\text {Leverage }} \\
& =\underbrace{\frac{\text { NetIncome }}{\text { Sales }}}_{\text {Margin }} \times \underbrace{\frac{\text { Sales }}{\text { Assets }}}_{\text {Turnover }} \times \frac{\text { Assets }}{\text { Equity }} .
\end{aligned}
$$

Table 6 examines how firms' index-inclusion incentives affected the behavior of the components of ROE above. In columns 1-4 of Panel A, we replicate our main baseline specification (column 4 of table 3) but use Forward ROA, Forward Profit Margin, Forward Asset Turnover, and Forward Leverage, respectively, as dependent variables. In Panel B, we run each specification of Panel A for the subset of companies with above or below median contemporaneous values in the ROE component of interest, in order to examine the cross-sectional variation in the types of channels different firms may utilize to increase ROE.

The results in Table 6 suggest that the improvement in ROE is largely driven by improving operations (increasing ROA), rather than through changing capital structure. Column 1 of Panel A reports a statistically significant (at the $5 \%$ level) treatment effect on Forward $R O A$ of 0.44 percentage points, a $14 \%$ increase over the treatment group's pre-period mean of $3.1 \%$. Column 2 of Panel A suggests that this increase in ROA is primarily driven by improved Forward Profit Margin: the statistically significant (at the $5 \%$ level) treatment effect estimate of 0.0069 constitutes a $14.4 \%$ increase in margins relative to their pre-period average of $4.8 \%$. Columns 1 and 2 of Panel $\mathrm{B}$ document that the increase in net margins is driven by the sub-sample of treatment firms with below-median margins: the coefficient on Treat $\times$ Post is significant only for the below-median profit margin sample, and the point estimate of the treatment effect is 0.0157 , more than twice the treatment effect for the full 
sample.

In contrast, our analysis of Forward Asset Turnover suggests that improvement in asset efficiency is not the dominant channel for the improvement in ROA. The treatment effect for the full-sample, reported in column 3 of Panel A is not statistically significant at the $10 \%$ level. However, the sub-sample analysis in columns 3 and 4 of Panel B reveals a statistically significant increase in turnover among those firms with below-median turnover. Nevertheless, this effect, at around $1.5 \%$ of the treatment group's average pre-period turnover, is economically much smaller than the treatment effect in profit margins.

Finally, we do not find any evidence that asset leverage was significantly impacted by firms' JPX400-inclusion incentives, both for the overall sample (column 4 of Panel A) as well as for the subsamples of above-median and below-median leverage firms (columns 5 and 6 of Panel B). These findings may not be entirely surprising, since JPX400's ranking algorithm does not necessarily incentivize firms to increase leverage per se. Under Modigliani and Miller (1958) assumptions, a profitable firm making a simple ceteris paribus increase in asset leverage - for example by issuing debt and repurchasing shares - would increase the company's ROE but might decrease its total market capitalization, a component of the selection algorithm.

On the other hand, it is possible that asset leverage might be too noisy of a measure to capture JPX400's potential effects on firm's capital structure decisions. We complement the analysis on leverage by examining the effect of the JPX400-inclusion incentives on payout policy, using shareholder payout ratio (i.e., dividends plus repurchases divided by shareholder's equity) as the dependent variable of interest. Treated firms could increase shareholder payouts in order to boost their ROE, by reducing retained earnings and the book value of shareholders equity, in particular if doing so leads shareholders to increase valuation 
multiples (thus dampening the potential trade off in market capitalization). In this way, we can interpret shareholder payouts as a financing choice that firms can employ to boost ROE, but where we are more likely to find a statistically measurable effect than in asset leverage. This variable is also of additional interest give that, as in (Ito, 2014), above, Japanese policymakers were interested in changing Japanese corporations cash-hoarding cultures.

In column 1 of Table 7, we find a statistically significant effect (at the $5 \%$ level) in shareholder payouts overall. Moreover, in columns 2 and 3 we show that that this effect is driven by the subsample of firms with more excess cash, that is those with above-median cash-to-equity ratio. This overall effect size - 0.5 percentage points - is economically large, representing approximately a $20 \%$ increase in payout ratio relative to the pre-period treatment group mean. However, relative to total assets the magnitude of the payouts are quite small: our estimates suggest that shareholder payouts represent $0.71 \%$ of the treatment group pre-period average assets. This might rationalize why an effect driven through the shareholder payouts channel might be statistically difficult to detect by examining asset leverage.

Together the analyses of Tables 6 and 7 show that JPX400-inclusion incentives drove firms to improve ROE through the channels where they had the most "slack." We find that the overall effects are driven by operating changes, that is by improving ROA. Nonetheless, we also find a significant increase in shareholder payouts.

\subsection{Accruals, Investments, R\&D, and Employment}

The results we have presented so far demonstrate that the JPX400 index drove a significant, robust improvement in ROE. However, an interesting question might be whether the index-inclusion incentives may have also produced perverse effects. For example, managers could have improved accounting earnings by manipulating accruals or by cutting productive 
investments, which could be contrary to the JPX400's broader goals of improving capital efficiency and social welfare in Japan. ${ }^{13}$

Table 8 explores these possibilities by estimating JPX400-inclusion incentive effects on four different outcome variables: Forward Accruals to Assets, Forward Log NOA, Forward RED to Sales, and Forward Log Employees. Each regression in this table employs the main specification from column 4 of Table 3: DID in the dependent variable of interest with firm-level controls and a control for the lagged dependent variable.

Column 1 reports the results of the specification with Forward Accruals to Assets as the dependent variable. We use income statement accruals as a proxy for earnings management. The coefficient on Treat $\times$ Post is not statistically significantly different from zero, suggesting that the increase in ROE is not driven by accruals-based earnings management.

Column 2 reports the results of the specification with $\log N O A$ as the dependent variable in order to examine the index-inclusion effects on "real" investments in net operating assets. Once again, in this specification we find no statistically significant treatment effect on $\log N O A$, suggesting that the JPX400 did not drive a statistically measurable change in investments in net operating assets.

Column 3 examines how firms alter R\&D intensity ( $R \& D$ expense to sales ratio) in response to the JPX400-inclusion incentives. R\&D is often seen as having positive externalities and long-term benefits that are not captured by the accounting system, but at the same time, as a discretionary expense item, managers might cut R\&D in order to boost reported earnings (e.g., Roychowdhury, 2006). R\&D expenditures could thus induce a trade-off between ROE and the macroeconomic and social-welfare goals of Japanese policymakers. We do

\footnotetext{
${ }^{13}$ A long literature in accounting, economics, and finance (e.g., Stein, 1989; Healy, 1985) has documented that incentivizing managers using relatively short-term earnings measures can produce the unintended, and potentially value-reducing, consequence of "short-termism" or earnings management.
} 
not find any evidence that treatment firms reduce R\&D intensity to improve ROE, as the coefficient on Treat $\times$ Post in column 3 are statistically and economically insignificant.

Finally, we examine how firm-level employment responds to the incentives generated by the JPX400. Japanese firms are well-known for having historically had an implicit system of lifetime employment. While this system has been weakened in recent years, Japanese firms are still more reluctant than Western firms to downsize employment. Some policymakers view these Japanese employment norms as a barrier to dynamism and growth, while others see it as providing social welfare benefits to Japanese workers. As such, policymakers involved in crafting the JPX400 index are likely interested in whether the index's incentives to increase profitability induced firms to downsize their employees.

Column 4 reports the result of the main DID specification with Forward Log Employees as the dependent variable. We find no evidence of statistically or economically significant changes in firm-level employment, suggesting that our main ROE result is unlikely to be driven by employee downsizing. Collectively, the results in Table 8 suggest that the main ROE effect we document is not driven by significant earnings management or significant cuts to investments in operating assets, R\&D, or employment.

\subsection{Market Valuation}

Our final analysis focuses on market valuation outcomes associated with JPX400-inclusion incentives. Table 9 reports the results of our main DID specification using Forward Book to Market ratio as the outcome variable of interest. Column 1 reports the results of a reducedform OLS DID with firm-level controls and time fixed effects. The negative, statistically significant coefficient on Treat $\times$ Post in this column indicates that treatment firms experienced a relative improvement in their valuations multiples. The point estimate of -.043 
represents a $3.8 \%$ decrease in book-to-market relative to the pre-period treatment-group mean of 1.14. This suggests that the improvement in ROE for treatment firms led to an upward revision in the market's expectations about their future cash-flows and that this revision was not compensated for by a commensurate increase in expectations of firm risk.

Columns 2 and 3 supplements this analysis by implementing a two stage least squares estimation of the effect of Forward ROE on Forward Book to Market, using the DID interaction as the instrument for Forward ROE. Column 2 reports the results of the first stage of the estimation, which is similar to our main result in Table 3. Column 3 reports the results of the second stage, which in effect regresses Forward Book to Market on the predicted values of Forward ROE. ${ }^{14}$ The negative, statistically significant coefficient on Forward ROE indicates that a 1 percentage point increase in ROE due to the JPX400-inclusion incentives is estimated to yield a decrease in Forward Book to Market of .023. In other words, a 1.9 percentage point increase in Forward ROE — the average of our DID estimates in Table 3) is expected to yield a decrease in Forward Book to Market of .044, which is a $3.8 \%$ decrease relative to the pre-period treatment mean and consistent with the reduced-form estimates in column 1. Overall, our evidence suggest that firms enjoyed an expansion in multiples as a result of their on-average increase in ROE due to the JPX400.

\section{Discussion of the JPX400's Overall Effect}

The JPX400 has generated significant interest among regulators, policy-makers, and investors in Japan and globally, and there is an active discussion on the efficacy of this index. We conclude our analysis by assessing the overall impact of the index.

\footnotetext{
${ }^{14}$ These estimates are obtained in one-step, so that the second-stage standard errors account for the first-stage estimation noise.
} 
In our view, comparing the realized returns of the JPX400 against other Japanese indices, as some policymakers and commentators do, does not reflect the success of the index, nor does it appropriately capture the incentive effects of the index on corporate performance and value in Japan. Such an approach faces two conceptual flaws. First, as our analyses above show, part of the effect of the index resides in the performance effects of firms that are excluded from the index but improving performance to earn a membership to the JPX400. Second, to the extent that the valuation benefits accrue to such firms prior to their inclusion in the JPX400 - either due to market participants responding to or anticipating firms' performance improvements resulting from JPX400-inclusion incentives - they would not be captured in the returns of the JPX400 index. Rather, the relative return comparison would attribute the beneficial effect of the JPX400 to the benchmark index. These two factors could explain why the JPX400 has underperformed the Nikkei225 over the three-year period from June 2014 to June 2017, and why some stocks outperform after being excluded from the JPX400.

Our research design avoids both of these conceptual issues above by leveraging differences in the intensity of JPX400-inclusion incentives and by focusing on a fundamental measure of performance (ROE). With our revised approach, we find that the JPX400 index has been substantially more successful than its portfolio returns would suggest.

To provide a conservative estimate of the JPX400's overall impact on the aggregate Japanese economy we focus on the incremental income generated by the firms we classify as "treated" as a result of their index-inclusion incentives. In untabulated results, we estimate a simple DID in forward net income using our baseline treatment and control groups, and find an on-average annual firm-level improvement in net income of JPY4.89 billions. Aggregating across the 200 firms in the treatment group yields an JPX400 effect on aggregate net income of JPY977.28 billion per year. This represents a $6.5 \%$ increase relative to 
the pre-period average aggregate income across all public Japanese firms (JPY15.05 trillion per year). Moreover, relative to the change in average aggregate net income from the preperiod to the post-period (from JPY15.05 trillion to JPY19.2 trillion per year), the effects attributable to the JPX400 accounts for $23.4 \%{ }^{15}$

To estimate the total wealth or valuation effects, we multiply the JPX400's net-income effect by a range of plausible incremental price-to-earnings $(\mathrm{P} / \mathrm{E})$ multiples. A very conservative and lower-bound incremental P/E ratio on the new profits generated by the JPX400 would be 1, for example if the incremental earnings are not expected to be plowed back. Under this assumption, the wealth effect would be JPY977.28 billion per year for a total of JPY1.95 trillion, or a $0.42 \%$ increase relative to the 2014 total Japanese market capitalization of JPY469 trillion. A less conservative incremental P/E ratio would be the treatment firms' cash-adjusted P/E ratio: (MCap - Cash)/NetIncome. ${ }^{16}$ The average cash-adjusted $\mathrm{P} / \mathrm{E}$ multiple for treated firms in the post period is 15.85 , implying a valuation impact of JPY30.91 trillion, or approximately $6.59 \%$ of the total market capitalization in 2014. Taking the midpoint of these estimates, our back-of-the-envelope estimation suggests that JPX400 improved the overall Japanese market's market capitalization by roughly $3 \%$.

These estimates may also be conservative to the extent that firms farther away from the threshold are still affected by, albeit to a lesser degree compared to those firms around the threshold of inclusion, JPX400-inclusion incentives. We emphasize, however, that these backof-envelope estimates are meant to characterize the approximate magnitude of JPX400's effect on Japanese corporate profitability and market capitalization. At face value, these

\footnotetext{
${ }^{15}$ We aggregate net income using the Datastream universe of public Japanese firms.

${ }^{16}$ This multiple is justified under the assumptions that a) the market values Japanese corporations' cash holdings 1-for-1, such that the cash-adjusted $\mathrm{P} / \mathrm{E}$ ratio captures the market's valuation of the companies' earnings; and b) the market perceived the income effect as sustainable, so that forecast growth and discount rates on the incremental profitability remained fixed.
} 
estimates would suggest that the JPX400 had a meaningful impact on aggregate corporate profitability and valuation.

\section{Conclusion}

We provide evidence that prestige - the shame from loss of prestige or aspiration to acquire prestige - can act as a powerful influence in how organizations and managers behave. Moreover, we show that stock indexes can be used as sources of prestige and thereby influence managerial and corporate behavior. In the case of Japan, where there are limits to contracting, our evidence suggests that a prestige index helped to resolve a long-standing corporate problem of low capital productivity. Our evidence suggests that for the firms around the threshold of inclusion, the prestige incentives produced economically large and statistically significant increases in ROE.

The evidence provided in this paper constitutes initial evidence that prestige-based incentives can be powerful in transforming corporate governance norms in settings like Japan. These findings can inform corporate governance reform efforts in capital markets that also have similar patterns of low capital efficiency and weak de facto shareholder rights, for example other East Asian economies like China, Korea, Singapore, or Taiwan. However, we stress that our evidence does not speak to the sustainability of these incentive effects.

We also believe that these findings are important in developed markets as well. Given the rising focus on limiting executive compensation in the U.S. and in Europe in recent years, we must understand alternative non-pecuniary mechanisms for inducing meaningful changes in corporate behavior. In Japan, the use of prestige indexes to transform corporate norms appears to be growing: in March 2017, TSE and Nikkei announced a new index, "JPX-Nikkei 
Mid and Small Cap Index," extending the profitability-based incentives to mid and small cap TSE-traded firms; more recently, MSCI announced the "Japan Empowering Women" index, backed by the GPIF, an index designed to shift the Japanese norms around gender diversity in the workplace. Globally, there is also a growing trend of ESG-based indexes. We look forward to further research in understanding the role of prestige incentives and transforming corporate norms through stock indexes in future research. 


\section{References}

Allen, F., E. Carletti, and R. Marquez (2015). Stakeholder governance, competition, and firm value. Review of Finance 19(3), 1315-1346.

Aoki, M., G. Jackson, and H. Miyajima (2007). Corporate Governance in Japan: Institutional Change and Organizational Diversity (1 ed.). Oxford, U.K.: Oxford University Press.

Avery, C., J. A. Chevalier, and S. Schaefer (1998). Why Do Managers Undertake Acquisitions? An Analysis of Internal and External Rewards for Acquisitiveness. Journal of Law, Economics, $\&$ Organization 14(1), 24-43.

Bebchuk, L. A. and J. M. Fried (2003). Executive Compensation as an Agency Problem. Journal of Economic Perspectives 17(3), 71-92.

Bertrand, M. (2009). CEOs. Annual Review of Economics 1(1), 121-150.

Buchanan, J., D. H. Chai, and S. Deakin (2013). Hedge Fund Activism in Japan: The Limits of Shareholder Primacy (1 ed.). Cambridge, UK: Cambridge University Press.

Chen, H., G. Noronha, and V. Singal (2004). The price response to S\&P 500 index additions and deletions: Evidence of asymmetry and a new explanation. Journal of Finance 59(4), 1901-1929.

Dhillon, U. and H. Johnson (1991). Changes in the Standard and Poor's 500 List. Journal of Business 64(1), 75-85.

Disney, R., S. Bridges, J. Gathergood, B. R. Disney, S. Bridges, and J. Gathergoodj (2006). The Impact of Merger Activity on Executive Pay in the United Kingdom. Economica $73(290), 321-339$.

Doh, J. P., S. D. Howton, S. W. Howton, and D. S. Siegel (2009). Does the Market Respond to an Endorsement of Social Responsibility? The Role of Institutions, Information, and Legitimacy. Journal of Management 36(6), 1461-1485.

Elster, J. (1989). Social norms and economic theory. Journal of Econonic Perspectives 3(4), 99.

Focke, F., E. Maug, and A. Niessen-Ruenzi (2017). The impact of firm prestige on executive compensation. Journal of Financial Economics 123(2), 313-336.

Harris, L. and E. Gurel (1986). Price and Volume Effects Associated with Changes in the S\&P 500 List: New Evidence for the Existence of Price Pressures. The Journal of Finance 41(4), 815-829. 
Harsanyi, J. (1966). A Bargaining Model for Social Stuts in Informal Groups and Formal Organizations. Systems Research and Behavioral Science 11(5), 357-369.

Hayek, F. A. (1967). Notes on the evolution of systems of rules of conduct. In Friedrich A. von Hayek (Ed.), Studies in Philosophy, Politics, and Economics, pp. 66-81. Chicago: University of Chicago Press.

Healy, P. M. (1985). The effect of bonus schemes on accounting decisions. Journal of Accounting and Economics 7, 85-107.

Ito, K. (2014). Ito Review of Competitiveness and Incentives for Sustainable Growth. Technical report.

Jensen, M. C. and W. H. Meckling (1976). Theory of the firm: Managerial behavior, agency costs and ownership structure. Journal of Financial Economics 3(4), 305-360.

Kato, K., M. Li, and D. J. Skinner (2017). Is Japan Really a Buy? The Corporate Governance, Cash Holdings and Economic Performance of Japanese Companies. Journal of Business Finance and Accounting 44(3-4), 480-523.

Kostritsky, J. P. (2013). The Law and Economics of Norms. Texas International Law Journal 48(3), 465-505.

Lynch, A. W. and R. R. Mendenhall (1997). New Evidence on Stock Price Effects Associated with Changes in the S \& P 500 Index. Journal of Business 70 (3), 351-383.

McLannahan, B. (2014). Japan groups take a shine to JPX-Nikkei 400 index. Financial Times (June 14).

Miller, D. T. and D. A. Prentice (2016). Changing Norms to Change Behavior. Annual Review of Psychology 6r(1), 339-361.

Modigliani, F. and M. H. Miller (1958). The Cost of Capital, Corporation Finance and the Theory of Investment. The American Economic Review 48(3), 261-297.

Oster, E. (2017). Unobservable Selection and Coefficient Stability: Theory and Validation. Journal of Business 85 Economic Statistics, Fothcoming.

Posner, R. A. and E. B. Rasmusen (1999). Creating and enforcing norms, with special reference to sanctions. International Review of Law and Economics 19(3), 369-382.

Raff, K. and L. Siming (2017). Knighthoods, damehoods, and CEO behaviour.

Roychowdhury, S. (2006). Earnings management through real activities manipulation. Journal of Accounting and Economics 42, 335-370. 
Shleifer, A. (1986). Do Demand Curves for Stocks Slope Down ? Meeting of the America Finance Association, New York, New York, December 28-30, 1985. Finance 41(3), 579-590.

Stein, J. C. (1989). Efficient capital markets, inefficient firms: a model of myopic corporate behavior. The Quarterly Journal of Economics November, 655-669.

Williamson, O. E. (1963). Managerial Discretion and Business Behavior. American Economic Review 53(5), 1032-1057.

Yoshimori, M. (1995). Whose company is it? The concept of the corporation in Japan and the west. Long Range Planning 28(4).

Zingales, L. (2015). Presidential Address: Does Finance Benefit Society? Journal of Finance $70(4), 1327-1363$. 
Fig. 1.

JPX400 Index Constituent Selection Time Line

Figure 1 is a schematic representation of the timeline of index selection, relative to the firm-level information, for each year of the JPX's existence. Panel A describes the timeline for the initial construction of the index, whereas Panel B describes the timeline for all future reconstitution of the index. Vertical lines indicate important dates for both initial construction, and future rebalancing of the index.

A: 2013

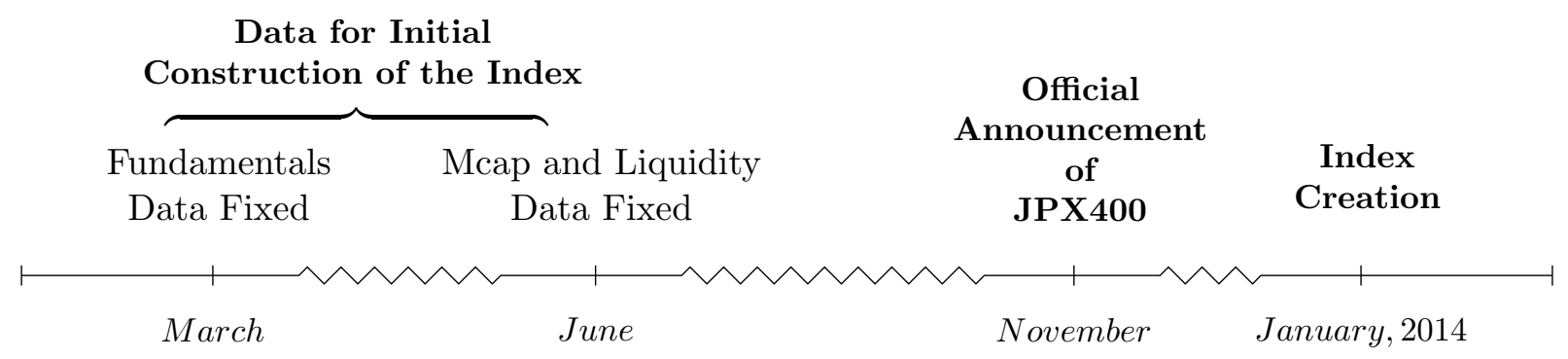

B: $2014+$

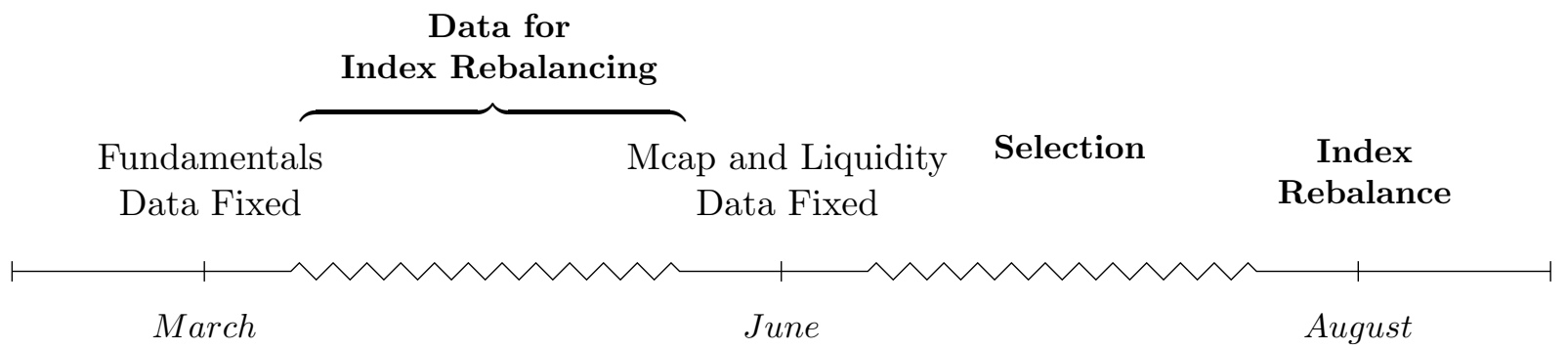


Fig. 2.

Sample Construction

Figure 2 is a schematic representation of the process we follow to arrive at our final sample. Steps (1) and (2) mimic the JPX400 selection algorithm. At the end of June of every calendar year we select the 1,200 most liquid firms trading in Japan and then subset this down further to the 1,000 largest, in terms of market capitalization. Thereafter we follow the JPX400 ranking algorithm and attach a synthetic JPX400 rank to each of these 1,000 firms. Finally, Step 3 describes how we assign treatment status based on this synthetic JPX400 rank. The top 400 firms are our predicted JPX400 constituents. For our baseline analysis, we classify firms with ranks on either side of this cutoff of 400, i.e., firms with ranks between 301-500 as our treatment group in every year, and firms with ranks between 501-800 as the corresponding control group. We do not include firms with ranks between 1-300 or 801-1,000 in our baseline analysis, but include them in robustness tests.

Step 1: In each June, Select Top 1,000 Firms by Market Capitalization and Liquidity

Step 2: Predict JPX400 Rank Using Data Available each June

Step 3: Construct Baseline Treatment and Control Sample

Predicted JPX400 Constituents

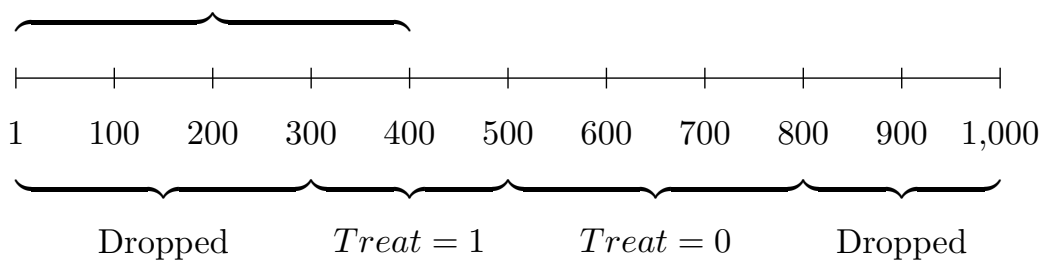




\section{Fig. 3. Placebo Tests by Time}

Figure 3 displays the results of placebo versions of our main analysis. We use historical data going back to 1991 to synthetically reconstruct JPX400 ranks and implement our main difference-in-difference test for six sets of years before the JPX400 index premiered. We mimic the temporal structure of our main analyses, i.e., we include six years for each analysis: three pre-treatment years and two post-treatment years with the treatment year being excluded. In this figure, the box's position on the y-axis represents the point estimate of the treatment effect, while the whiskers represent the $95 \%$ confidence interval. The year on the x-axis represents the first treatment year for the six-year period for which the treatment effect was estimated. The first year we use in this graph is 1997, because our data goes back to 1991, and three years of data are required to construct a JPX400 rank, so our first pre-period starts from 1994. We space these estimates out three years apart in order to avoid overlapping treatment and control groups across estimates.

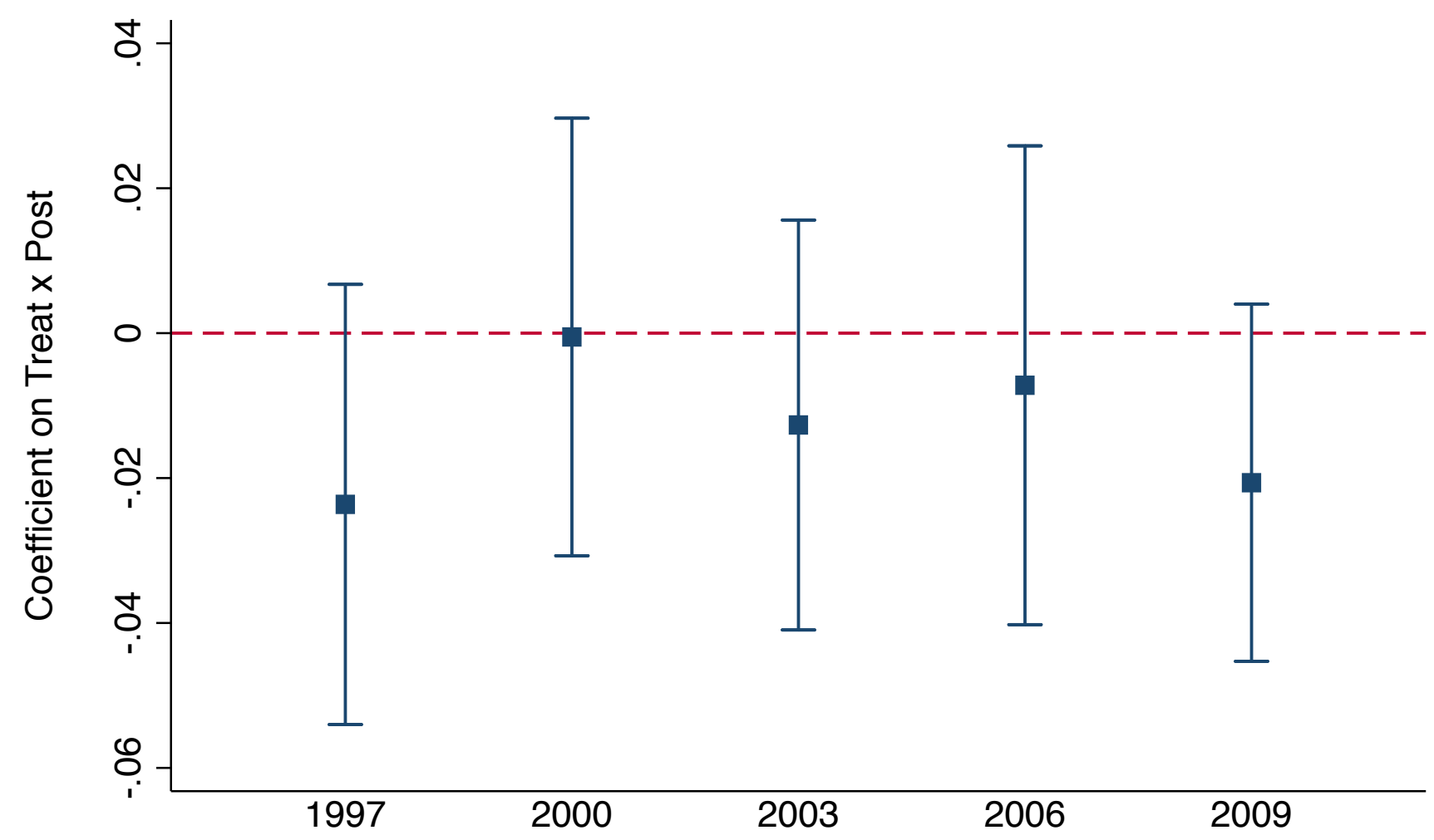

Post Period Indicator in Time-Placebo Test 
Table A1.

Description of Variables

This table presents definitions of variables used in our analysis. All data were obtained from the Thomson Reuters Datastream database.

\begin{tabular}{|c|c|c|}
\hline Variable & Description & Computation \\
\hline$R O E$ & Return on equity & $\begin{array}{l}\text { Net Income [WC07250] / Total Shareholders' Equity } \\
\text { [WC03995] }\end{array}$ \\
\hline$R O A$ & Return on assets & Net Income [WC07250] / Total Assets [WC02999] \\
\hline Profit margin & Net profit margin & Net income [WC07250] / Revenues [WC07240] \\
\hline Asset Turnover & & Revenues [WC07240] / Total Assets [WC02999] \\
\hline Leverage & Asset leverage & $\begin{array}{l}\text { Total Assets [WC02999] / Total Shareholders' Eq- } \\
\text { uity [WC03995] }\end{array}$ \\
\hline Repurchases & Estimated repurchases & $\begin{array}{l}\text { Funds to Decrease Common or Preferred Stock } \\
\text { [WC04751] - Change in Preferred Stock [WC03451] }\end{array}$ \\
\hline Dividends to Equity & & $\begin{array}{l}\text { Cash Dividends Paid [WC04551] / Total Sharehold- } \\
\text { ers' Equity [WC03995] }\end{array}$ \\
\hline Shareholder Payouts & & $\begin{array}{l}\text { (Repurchases + Cash Dividends Paid) / Total Share- } \\
\text { holders' Equity [WC03995] }\end{array}$ \\
\hline Book to Market & & $\begin{array}{l}\text { Total Shareholders' Equity [WC03995] / Market } \\
\text { Value [MV] }\end{array}$ \\
\hline Accruals to Assets & & $\begin{array}{l}\text { (Net Income [WC07250] - Funds from Operations } \\
{[\text { WC04201]) / Total Assets [WC02999] }}\end{array}$ \\
\hline $\log N O A$ & $\begin{array}{l}\text { Natural logarithm of net op- } \\
\text { erating assets }\end{array}$ & $\begin{array}{l}\ln (\text { Long-Term Debt [WC03251] - Cash \& Short- } \\
\text { Term Investments [WC02001] + Total Shareholders } \\
\text { Equity [WC03995]) }\end{array}$ \\
\hline RED to Sales & & R\&D Expenses [WC01201] / Revenues [WC07240] \\
\hline Log Employees & $\begin{array}{l}\text { Natural logarithm of the } \\
\text { number of employees }\end{array}$ & $\ln ($ Employees [WC07011]) \\
\hline Cash to Equity & & $\begin{array}{l}\text { Cash \& Short-Term Investments [WC02001] / Total } \\
\text { Shareholders' Equity [WC03995] }\end{array}$ \\
\hline Lagged Annual Return & & $\begin{array}{l}\text { Net Annual Buy and Hold Returns, computed using } \\
\text { the Total Return Index [RI] }\end{array}$ \\
\hline Log Market Cap & $\begin{array}{l}\text { Natural logarithm of market } \\
\text { capitalization }\end{array}$ & $\ln ($ Market Value $[\mathrm{MV}])$ \\
\hline LT Debt to Equity & & $\begin{array}{l}\text { Long-Term Debt [WC03251] / Total Shareholders' } \\
\text { Equity [WC03995] }\end{array}$ \\
\hline Sales Growth & & Revenues [WC07240] / Lagged Revenues [WC07240] \\
\hline Nikkei225 & $\begin{array}{l}\text { Indicator for company's in- } \\
\text { clusion in Nikkei } 225 \text { index at } \\
\text { the time of the JPX } 400 \text { selec- } \\
\text { tion in the given year }\end{array}$ & \\
\hline
\end{tabular}


Table 1.

Predicting JPX400 Membership

This table reports OLS regressions of Actual Inclusion, an indicator denoting whether a firm is actually part of the JPX, on Predicted Inclusion - our quantitative algorithm's prediction of whether the firm will be included in the JPX, i.e., the firm's synthetic rank is between 1-400. Column 3 reports results where Predicted Inclusion is dis-aggregated into two separate indicators, indicating whether a firm's synthetic rank is between 1-200 or between 200-400. Three other indicators are also included in the regression, for ranks between 400-600,600-800, and for those outside 800. For column 3, the last indicator subsumes the constant term in the regression. Columns 2 and 4 include other specified firm-level controls. The sample includes firms with synthetic ranks from 1-2000 for the years 2013-2015. Standard errors, clustered at the firm-level, are reported in parentheses. Significance levels are indicated by ${ }^{*},{ }^{* *},{ }^{* * *}$ for $10 \%, 5 \%$, and $1 \%$, respectively.

\begin{tabular}{|c|c|c|c|c|}
\hline & $\begin{array}{c}(1) \\
\text { Actual Inclusion }\end{array}$ & $\begin{array}{c}(2) \\
\text { Actual Inclusion }\end{array}$ & $\begin{array}{c}(3) \\
\text { Actual Inclusion }\end{array}$ & $\begin{array}{c}(4) \\
\text { Actual Inclusion }\end{array}$ \\
\hline Predicted Inclusion & $\begin{array}{c}0.923^{* * *} \\
(0.01)\end{array}$ & $\begin{array}{c}0.863^{* * *} \\
(0.01)\end{array}$ & & \\
\hline Rank 1-200 & & & $\begin{array}{c}0.993^{* * *} \\
(0.00)\end{array}$ & $\begin{array}{c}0.949^{* * *} \\
(0.01)\end{array}$ \\
\hline Rank $201-400$ & & & $\begin{array}{c}0.877^{* * *} \\
(0.02)\end{array}$ & $\begin{array}{c}0.854^{* * *} \\
(0.02)\end{array}$ \\
\hline Rank $401-600$ & & & $\begin{array}{c}0.0544^{* * *} \\
(0.01)\end{array}$ & $\begin{array}{c}0.0458^{* * *} \\
(0.01)\end{array}$ \\
\hline Rank $601-800$ & & & $\begin{array}{c}0 \\
(.)\end{array}$ & $\begin{array}{l}0 \\
(.)\end{array}$ \\
\hline Rank outside 800 & & & $\begin{array}{l}0.00554^{* * *} \\
\quad(0.00)\end{array}$ & $\begin{array}{c}0.0330^{* * *} \\
(0.01)\end{array}$ \\
\hline Log Market Cap & & $\begin{array}{l}0.0225^{* * *} \\
(0.00)\end{array}$ & & $\begin{array}{c}0.0193^{* * *} \\
(0.00)\end{array}$ \\
\hline Book to Market & & $\begin{array}{c}-0.00217 \\
(0.00)\end{array}$ & & $\begin{array}{c}-0.00183 \\
(0.00)\end{array}$ \\
\hline Sales Growth & & $\begin{array}{c}-0.00407 \\
(0.02)\end{array}$ & & $\begin{array}{c}-0.00382 \\
(0.02)\end{array}$ \\
\hline LT Debt to Equity & & $\begin{array}{c}-0.00423 \\
(0.00)\end{array}$ & & $\begin{array}{c}-0.00349 \\
(0.00)\end{array}$ \\
\hline Cash to Equity & & $\begin{array}{c}0.00473 \\
(0.01)\end{array}$ & & $\begin{array}{c}0.00186 \\
(0.01)\end{array}$ \\
\hline Observations & 5,327 & 5,327 & 5,327 & 5,327 \\
\hline$R^{2}$ & 0.866 & 0.870 & 0.898 & 0.874 \\
\hline
\end{tabular}


Table 2.

Summary Statistics

Table 2 reports summary statistics, for the pre-treatment period, i.e., 2010-2012, for the full sample used for the main regressions (firms ranked 300-800 according to the quantitative algorithm). The last three columns of the table report the means separately for the treatment (ranks 300-500) and control (ranks 500-800) groups, and also reports the t-test comparing the means of the two groups. All continuous variables are winsorized at the $1 \%$ level.

\begin{tabular}{|c|c|c|c|c|c|c|c|c|}
\hline & \multicolumn{5}{|c|}{ Full Pre-Period Sample } & \multirow[b]{2}{*}{$\begin{array}{c}\text { Mean } \\
\text { Treat }=1\end{array}$} & \multirow[b]{2}{*}{$\begin{array}{c}\text { Mean } \\
\text { Treat }=0\end{array}$} & \multirow[b]{2}{*}{$\begin{array}{l}\text { T-Stat of } \\
\text { Difference }\end{array}$} \\
\hline & $p 25$ & Mean & $p 50$ & $p 75$ & $S D$ & & & \\
\hline$R O E$ & 0.0300 & 0.0550 & 0.0500 & 0.0822 & 0.0884 & 0.0596 & 0.0519 & 1.6001 \\
\hline$R O A$ & 0.0088 & 0.0283 & 0.0238 & 0.0428 & 0.0368 & 0.0307 & 0.0267 & 2.0749 \\
\hline Profit Margin & 0.0136 & 0.0465 & 0.0302 & 0.0600 & 0.0792 & 0.0477 & 0.0457 & 0.4654 \\
\hline Asset Turnover & 0.6096 & 0.9563 & 0.9017 & 1.2474 & 0.6166 & 1.0078 & 0.9223 & 2.5620 \\
\hline Leverage & 1.5845 & 3.6636 & 2.0722 & 3.2282 & 4.6230 & 3.7509 & 3.6059 & 0.6030 \\
\hline Repurchases to Equity & 0.0000 & 0.0058 & 0.0000 & 0.0002 & 0.0222 & 0.0054 & 0.0061 & -0.5131 \\
\hline Dividends to Equity & 0.0115 & 0.0204 & 0.0170 & 0.0241 & 0.0146 & 0.0213 & 0.0198 & 2.0098 \\
\hline Book to Market & 0.8233 & 1.2184 & 1.1610 & 1.5203 & 0.5660 & 1.1371 & 1.2720 & -4.6767 \\
\hline Lagged Annual Return & -0.1662 & -0.0363 & -0.0106 & 0.1318 & 0.2740 & -0.0405 & -0.0336 & -0.4801 \\
\hline Accruals to Assets & -0.0648 & -0.0440 & -0.0428 & -0.0197 & 0.0354 & -0.0455 & -0.0429 & -1.3838 \\
\hline $\log N O A$ & 17.2196 & 18.0254 & 18.0131 & 18.8099 & 1.3192 & 18.3989 & 17.7764 & 8.3809 \\
\hline RED to Sales & 0.0000 & 0.0141 & 0.0018 & 0.0180 & 0.0282 & 0.0109 & 0.0162 & -3.6708 \\
\hline Log Employees & 6.5917 & 7.4610 & 7.5570 & 8.2960 & 1.3597 & 7.5423 & 7.4068 & 1.7884 \\
\hline Log Market Cap & 17.4739 & 18.0956 & 17.9632 & 18.6202 & 0.8724 & 18.5122 & 17.8206 & 15.5258 \\
\hline Sales Growth & 0.9371 & 1.0134 & 1.0049 & 1.0746 & 0.1628 & 1.0099 & 1.0157 & -0.6852 \\
\hline LT Debt to Equity & 0.0179 & 0.3896 & 0.1600 & 0.4882 & 0.6026 & 0.4587 & 0.3440 & 3.4864 \\
\hline Cash to Equity & 0.1877 & 0.3851 & 0.3048 & 0.4415 & 0.3555 & 0.3904 & 0.3817 & 0.4435 \\
\hline Nikkei 225 & 0.0000 & 0.1441 & 0.0000 & 0.0000 & 0.3513 & 0.2064 & 0.1030 & 5.3198 \\
\hline
\end{tabular}


Table 3.

Treatment Effects in ROE

Table 3 reports the results of DID regressions using one-year-ahead return on equity, Forward ROE, as the dependent variables. Treat, an indicator denoting the treatment group, is equal to one for firms ranked 300-500 under the JPX400 selection algorithm and zero for firms ranked 500-800. Post, is an indicator variable assuming the value one for years 2014-2015, and zero for the pre-treatment period, i.e., 2010-2012. Column 1 reports results using year fixed effects. Column 2 reports results using year fixed effects and industry fixed effects, with industry defined by Datastream's Industry Level 3 Name (INDM3). Column 3 reports results using time and industry fixed effects, and adding controls as specified. Column 4 reports results using contemporaneous ROE as a control as well as specified controls and time fixed effects. Column 5 examines differential pre-treatment treatment trends by decomposing Treat into three mutually exclusive indicators — one for each of the three pre-treatment periods: 2010,2011,and 2012. All variables are defined in Table A1. Standard errors, clustered at the firm level, are reported in parentheses. Significance levels are indicated by ${ }^{*},{ }^{* *},{ }^{* * *}$ for $10 \%, 5 \%$, and $1 \%$, respectively.

\begin{tabular}{|c|c|c|c|c|c|}
\hline & $\begin{array}{c}(1) \\
\text { Forward ROE }\end{array}$ & $\begin{array}{c}(2) \\
\text { Forward } R O E\end{array}$ & $\begin{array}{c}(3) \\
\text { Forward } R O E\end{array}$ & $\begin{array}{c}(4) \\
\text { Forward } R O E\end{array}$ & $\begin{array}{c}(5) \\
\text { Forward } R O E\end{array}$ \\
\hline Treat x Post & $\begin{array}{c}0.021^{* *} \\
(0.01)\end{array}$ & $\begin{array}{c}0.020^{* *} \\
(0.01)\end{array}$ & $\begin{array}{c}0.018^{* *} \\
(0.01)\end{array}$ & $\begin{array}{c}0.019^{* * *} \\
(0.01)\end{array}$ & $\begin{array}{c}0.018^{* *} \\
(0.01)\end{array}$ \\
\hline Treat & $\begin{array}{l}-0.005 \\
(0.01)\end{array}$ & $\begin{array}{l}-0.005 \\
(0.01)\end{array}$ & $\begin{array}{l}0.006 \\
(0.01)\end{array}$ & $\begin{aligned}-0.008^{*} \\
(0.00)\end{aligned}$ & $\begin{array}{l}-0.008 \\
(0.01)\end{array}$ \\
\hline Post & $\begin{array}{c}0.019^{* * *} \\
(0.01)\end{array}$ & & & & \\
\hline Treat $\mathrm{x}($ Year $=2011)$ & & & & & $\begin{array}{r}-0.007 \\
(0.01)\end{array}$ \\
\hline Treat $\mathrm{x}($ Year $=2012)$ & & & & & 0.004 \\
\hline$R O E$ & & & & $\begin{array}{c}0.516^{* * *} \\
(0.07)\end{array}$ & $\begin{array}{c}0.517^{* * *} \\
(0.07)\end{array}$ \\
\hline Log Market Cap & & & $\begin{array}{c}-0.026^{* * *} \\
(0.00)\end{array}$ & $\begin{array}{c}-0.007^{* *} \\
(0.00)\end{array}$ & $\begin{array}{c}-0.007^{* *} \\
(0.00)\end{array}$ \\
\hline Book to Market & & & $\begin{array}{c}-0.075^{* * *} \\
(0.01)\end{array}$ & $\begin{array}{c}-0.042^{* * *} \\
(0.01)\end{array}$ & $\begin{array}{c}-0.042^{* * *} \\
(0.01)\end{array}$ \\
\hline Sales Growth & & & $\begin{array}{c}0.055^{* * *} \\
(0.02)\end{array}$ & $\begin{array}{r}-0.018 \\
(0.02)\end{array}$ & $\begin{array}{r}-0.018 \\
(0.02)\end{array}$ \\
\hline LT Debt to Equity & & & $\begin{array}{c}-0.014^{* *} \\
(0.01)\end{array}$ & $\begin{array}{c}-0.010^{* *} \\
(0.00)\end{array}$ & $\begin{array}{c}-0.010^{* *} \\
(0.00)\end{array}$ \\
\hline Cash to Equity & & & $\begin{array}{r}-0.008 \\
(0.01) \\
\end{array}$ & $\begin{array}{l}0.002 \\
(0.01) \\
\end{array}$ & $\begin{array}{l}0.002 \\
(0.01) \\
\end{array}$ \\
\hline Time FE & No & Yes & Yes & Yes & Yes \\
\hline Industry FE & No & No & Yes & No & No \\
\hline Observations & 2,319 & 2,319 & 2,319 & 2,319 & 2,319 \\
\hline$R^{2}$ & 0.0230 & 0.0234 & 0.2886 & 0.3901 & 0.3899 \\
\hline
\end{tabular}


Table 4.

JPX400 Index-Inclusion Incentives

This table reports the results of various tests, similar to the main DID in Table 3, but with alternate treatment and control definitions. Column (1) reports the results for the main DID regression with Treat now partitioned into two separate treatment groups - firms ranked 301-400 (those who just make the JPX400 cutoff) and firms ranked 401-500 (those that just miss the cutoff). The F-test, and the corresponding p-value, for this column compares the treatment effect for firms that just made vs. those that just missed the JPX400 cutoff. Column (2) estimates a DID regression with the sample extended to the firms ranked from 1-300 and includes a separate treatment effect for these firms ranked above our main treatment group of interest (Ranks 301-500). The F-statistic, and the corresponding p-value, reported in this column pertain to a Wald test comparing the two treatment effects. Column (3) mimics the structure of our main DID specification in Column (4) of Table 3, but is estimated over a placebo group of treatment and control firms i.e. firms ranked from 1301-1800. Column (4) expands the sample from column (2) further to include the top 1000 firms, but here our treatment variable of interest, Quintile(Closeness), is more granular and indicates the particular quintile in which a firm falls, in terms of its distance from the rank-cutoff of 400. All variables are defined in Table A1. Standard errors, clustered at the firm level, are reported in parentheses. Significance levels are indicated by ${ }^{*},{ }^{* *},{ }^{* * *}$ for $10 \%, 5 \%$, and $1 \%$, respectively.

\begin{tabular}{|c|c|c|c|c|}
\hline & $\begin{array}{c}(1) \\
\text { Forward ROE }\end{array}$ & $\begin{array}{c}(2) \\
\text { Forward } R O E\end{array}$ & $\begin{array}{c}(3) \\
\text { Forward } R O E\end{array}$ & $\begin{array}{c}(4) \\
\text { Forward } R O E\end{array}$ \\
\hline Treat x Rank 301-400 x Post & $\begin{array}{c}0.019^{* *} \\
(0.01)\end{array}$ & & & \\
\hline Treat x Rank 401-500 x Post & $\begin{array}{c}0.018^{* *} \\
(0.01)\end{array}$ & & & \\
\hline Treat $\mathrm{x}$ Post & & $\begin{array}{c}0.019^{* * *} \\
(0.01)\end{array}$ & & \\
\hline Rank 1-300 x Post & & $\begin{array}{l}0.006 \\
(0.01)\end{array}$ & & \\
\hline Placebo Group Treat x Post & & & $\begin{array}{l}0.006 \\
(0.01)\end{array}$ & \\
\hline Quintile(Closeness) x Post & & & & $\begin{array}{c}0.007^{* * *} \\
(0.00)\end{array}$ \\
\hline Treat x Rank 301-400 & $\begin{array}{l}-0.004 \\
(0.01)\end{array}$ & & & \\
\hline Treat x Rank 401-500 & $\begin{aligned}-0.012^{*} \\
(0.01)\end{aligned}$ & & & \\
\hline Treat & & $\begin{array}{c}-0.012^{* *} \\
(0.00)\end{array}$ & & \\
\hline Rank 1-300 & & $\begin{array}{l}0.003 \\
(0.00)\end{array}$ & & \\
\hline Placebo Group Treat & & & $\begin{array}{l}0.010^{*} \\
(0.00)\end{array}$ & \\
\hline Quintile(Closeness) & & & & $\begin{array}{c}-0.003^{*} \\
(0.00)\end{array}$ \\
\hline$R O E$ & $\begin{array}{c}0.512^{* * *} \\
(0.07) \\
\end{array}$ & $\begin{array}{c}0.553^{* * *} \\
(0.05) \\
\end{array}$ & $\begin{array}{c}0.285^{* * *} \\
(0.05) \\
\end{array}$ & $\begin{array}{c}0.433^{* * *} \\
(0.04) \\
\end{array}$ \\
\hline Time FE & Yes & Yes & Yes & Yes \\
\hline Firm Controls & Yes & Yes & Yes & Yes \\
\hline Observations & 2,319 & 3,718 & 2,400 & 4,610 \\
\hline$R^{2}$ & 0.3903 & 0.4307 & 0.1886 & 0.3321 \\
\hline F-stat & 0.004 & 5.966 & & \\
\hline$p$-value & 0.948 & 0.015 & & \\
\hline
\end{tabular}


Table 5.

Prestige vs. Other Index-Inclusion Incentives

This table reports the results of various tests to identify the incentives driving the earlier results. Column (1) reverts to our original definition of Treat, i.e., firms ranked 301-500, and using the full sample of 1000 firms, estimates differential treatment effect for firms which are in the Nikkei225 vs those which are not. This is achieved by interacting our treatment indicator with an indicator for contemporaneous Nikkei225 membership. Column (2) replicates the analysis in column (3), but now replaces Treat with Quintile(Closeness). The last two rows, for columns (1) and (2),report the results of Wald tests comparing the differential treatment effects. Columns (3) and (4) report triple-difference versions of the tests in columns (1) and (2), where we allow firms in the Nikkei225 to have a different pre-treatment average. For all columns, we include time fixed effects and firm controls, as in Table 3. All variables are defined in Table A1. Standard errors, clustered at the firm level, are reported in parentheses. Significance levels are indicated by ${ }^{*},{ }^{* *},{ }^{* * *}$ for $10 \%, 5 \%$, and $1 \%$, respectively.

\begin{tabular}{|c|c|c|c|c|}
\hline & \multicolumn{2}{|c|}{ Splitting Treatment } & \multicolumn{2}{|c|}{ Triple Diffs } \\
\hline & (1) & $(2)$ & (3) & (4) \\
\hline Treat $\mathrm{x}$ Nikkei225 $\mathrm{x}$ Post & $\begin{array}{c}0.050^{* * *} \\
(0.02)\end{array}$ & & $\begin{array}{l}0.034^{*} \\
(0.02)\end{array}$ & \\
\hline Treat x non-Nikkei225 x Post & $\begin{array}{c}0.013^{* *} \\
(0.01)\end{array}$ & & & \\
\hline Quintile(Closeness) x Nikkei225 x Post & & $\begin{array}{c}0.012^{* * * *} \\
(0.00)\end{array}$ & & $\begin{array}{l}0.012^{*} \\
(0.01)\end{array}$ \\
\hline Quintile(Closeness) x non-Nikkei225 x Post & & $\begin{array}{c}0.006^{* * *} \\
(0.00)\end{array}$ & & \\
\hline Quintile(Closeness) x Post & & & & $\begin{array}{c}0.005^{* *} \\
(0.00)\end{array}$ \\
\hline Nikkei225 x Post & & & $\begin{array}{l}0.003 \\
(0.01)\end{array}$ & $\begin{array}{l}-0.016 \\
(0.02)\end{array}$ \\
\hline Treat $\mathrm{x}$ Post & & & $\begin{array}{c}0.014^{* *} \\
(0.01)\end{array}$ & \\
\hline Treat x Nikkei225 & $\begin{array}{c}-0.044^{* * *} \\
\quad(0.02)\end{array}$ & & $\begin{array}{c}-0.033^{* *} \\
(0.02)\end{array}$ & \\
\hline Treat x non-Nikkei225 & $\begin{array}{r}-0.004 \\
(0.00)\end{array}$ & & & \\
\hline Quintile(Closeness) x Nikkei225 & & $\begin{array}{l}-0.009^{* * *} \\
(0.00)\end{array}$ & & $\begin{array}{c}-0.010^{* *} \\
(0.00)\end{array}$ \\
\hline Quintile(Closeness) x non-Nikkei225 & & $\begin{array}{r}-0.001 \\
(0.00)\end{array}$ & & \\
\hline Quintile(Closeness) & & & & $\begin{array}{l}-0.001 \\
(0.00)\end{array}$ \\
\hline Nikkei225 & & & $\begin{array}{c}-0.009^{*} \\
(0.00)\end{array}$ & $\begin{array}{l}0.006 \\
(0.01)\end{array}$ \\
\hline Treat & & & $\begin{array}{r}-0.006 \\
(0.00)\end{array}$ & \\
\hline$R O E$ & $\begin{array}{c}0.429^{* * *} \\
(0.04)\end{array}$ & $\begin{array}{c}0.426^{* * *} \\
(0.04)\end{array}$ & $\begin{array}{c}0.428^{* * *} \\
(0.04)\end{array}$ & $\begin{array}{c}0.426^{* * *} \\
(0.04)\end{array}$ \\
\hline Time FE & Yes & Yes & Yes & Yes \\
\hline Firm Controls & Yes & Yes & Yes & Yes \\
\hline Observations & 4,610 & 4,610 & 4,610 & 4,610 \\
\hline$R^{2}$ & 0.3339 & 0.3347 & 0.3341 & 0.3347 \\
\hline F-stat & 5.375 & 5.822 & & \\
\hline$p$-value & 0.021 & 0.016 & & \\
\hline
\end{tabular}


Table 6.

Components of ROE

Table 6 reports the results of DID regressions using the values of the DuPont Decomposition components of ROE - Forward ROA, Forward Profit Margins, Forward Asset Turnover, and Forward Leverage - as dependent variables. As in Table 3, Treat is equal to one for firms ranked 300-500 under the JPX400 selection algorithm and zero for firms ranked 500-800, while Post is an indicator variable assuming the value one for years 2014-2015, and zero for the pre-treatment period, i.e., 2010-2012. Panel A reports the results of regressions estimated on the full sample, while Panel $B$ reports separate regressions for each dependent variable with the sample split on above- vs. below-median contemporaneous levels of the dependent variable. In Panel A, all specifications use the same controls and year fixed effects, and vary to include the contemporaneous version of the dependent variable as a control. In Panel B, each pair of regressions differ based off of the above- vs. below-median dependent variable sample split. The starting sample for all analyses is one for which all variables used in the baseline analysis, i.e., columns (3) - (5) of Table 3, are available. All variables are defined in Table A1. Standard errors, clustered at the firm level, are reported in parentheses. Significance levels are indicated by ${ }^{*},{ }^{* *},{ }^{* * *}$ for $10 \%, 5 \%$, and $1 \%$, respectively.

Panel A: DuPont Decomposition

\begin{tabular}{|c|c|c|c|c|}
\hline & $\begin{array}{c}(1) \\
\text { Forward } \\
\text { ROA }\end{array}$ & $\begin{array}{c}(2) \\
\text { Forward } \\
\text { Profit Margins }\end{array}$ & $\begin{array}{c}(3) \\
\text { Forward } \\
\text { Asset Turnover }\end{array}$ & $\begin{array}{c}(4) \\
\text { Forward } \\
\text { Leverage }\end{array}$ \\
\hline Treat x Post & $\begin{array}{c}0.0044^{* *} \\
(0.002)\end{array}$ & $\begin{array}{c}0.0069^{* *} \\
(0.003)\end{array}$ & $\begin{array}{c}0.0011 \\
(0.009)\end{array}$ & $\begin{array}{l}-0.0368 \\
(0.052)\end{array}$ \\
\hline Treat & $\begin{array}{c}-0.0029 \\
(0.002)\end{array}$ & $\begin{array}{c}-0.0128^{* * *} \\
(0.003)\end{array}$ & $\begin{array}{c}-0.0177^{* * *} \\
(0.006)\end{array}$ & $\begin{array}{c}0.0162 \\
(0.033)\end{array}$ \\
\hline$R O A$ & $\begin{array}{c}0.5990^{* * *} \\
(0.045)\end{array}$ & & & \\
\hline Profit Margin & & $\begin{array}{c}0.8416^{* * *} \\
(0.040)\end{array}$ & & \\
\hline Asset Turnover & & & $\begin{array}{c}0.9635^{* * *} \\
(0.006)\end{array}$ & \\
\hline Leverage & & & & $\begin{array}{c}0.8544^{* * *} \\
(0.056)\end{array}$ \\
\hline Log Market Cap & $\begin{array}{c}-0.0019^{* *} \\
(0.001)\end{array}$ & $\begin{array}{c}0.0046^{* * *} \\
(0.001)\end{array}$ & $\begin{array}{c}0.0083^{* * *} \\
(0.003)\end{array}$ & $\begin{array}{c}0.0692^{* * *} \\
(0.023)\end{array}$ \\
\hline Book to Market & $\begin{array}{c}-0.0187^{* * *} \\
(0.002)\end{array}$ & $\begin{array}{c}-0.0164^{* * *} \\
(0.003)\end{array}$ & $\begin{array}{c}-0.0161^{* * *} \\
(0.006)\end{array}$ & $\begin{array}{c}0.1521^{* * *} \\
(0.048)\end{array}$ \\
\hline Sales Growth & $\begin{array}{c}-0.0115^{*} \\
(0.006)\end{array}$ & $\begin{array}{c}-0.0350^{* * *} \\
(0.010)\end{array}$ & $\begin{array}{c}-0.0406^{*} \\
(0.024)\end{array}$ & $\begin{array}{c}-0.0706 \\
(0.110)\end{array}$ \\
\hline LT Debt to Equity & $\begin{array}{c}-0.0055^{* * *} \\
(0.001)\end{array}$ & $\begin{array}{l}0.0009 \\
(0.002)\end{array}$ & $\begin{array}{l}-0.0006 \\
(0.004)\end{array}$ & $\begin{array}{c}0.3312^{* *} \\
(0.140)\end{array}$ \\
\hline Cash to Equity & $\begin{array}{l}-0.0018 \\
(0.002)\end{array}$ & $\begin{array}{l}0.0003 \\
(0.004)\end{array}$ & $\begin{array}{r}-0.0120 \\
(0.008)\end{array}$ & $\begin{array}{c}0.1968 \\
(0.139)\end{array}$ \\
\hline Time FE & Yes & Yes & Yes & Yes \\
\hline Observations & 2,319 & 2,319 & 2,319 & 2,319 \\
\hline$R^{2}$ & 0.5418 & 0.6689 & 0.9604 & 0.8802 \\
\hline
\end{tabular}


Table 6. Continued

Panel B: Subsample Analysis

\begin{tabular}{|c|c|c|c|c|c|c|}
\hline & \multicolumn{2}{|c|}{ Forward Profit Margin } & \multicolumn{2}{|c|}{ Forward Asset Turnover } & \multicolumn{2}{|c|}{ Forward Asset Leverage } \\
\hline & $\begin{array}{c}\text { (1) } \\
\text { Below-Median } \\
\text { Profit Margin }\end{array}$ & $\begin{array}{l}\qquad(2) \\
\text { Above-Median } \\
\text { Profit Margin }\end{array}$ & $\begin{array}{c}\text { (3) } \\
\text { Below-Median } \\
\text { Asset Turn }\end{array}$ & $\begin{array}{c}(4) \\
\text { Above-Median } \\
\text { Asset Turn }\end{array}$ & $\begin{array}{l}\quad(5) \\
\text { Below-Median } \\
\text { Asset Leverage }\end{array}$ & $\begin{array}{c}\text { (6) } \\
\text { Above-Median } \\
\text { Asset Leverage }\end{array}$ \\
\hline Treat x Post & $\begin{array}{c}0.0157^{* * *} \\
(0.005)\end{array}$ & $\begin{array}{l}0.0005 \\
(0.005)\end{array}$ & $\begin{array}{c}0.0149^{*} \\
(0.008)\end{array}$ & $\begin{array}{r}-0.0131 \\
(0.016)\end{array}$ & $\begin{array}{l}0.0001 \\
(0.021)\end{array}$ & $\begin{array}{l}-0.0507 \\
(0.111)\end{array}$ \\
\hline Treat & $\begin{array}{c}-0.0096^{* *} \\
(0.004)\end{array}$ & $\begin{array}{c}-0.0099^{* *} \\
(0.004)\end{array}$ & $\begin{array}{c}-0.0265^{* * *} \\
(0.006)\end{array}$ & $\begin{array}{l}-0.0093 \\
(0.010)\end{array}$ & $\begin{array}{c}-0.0264^{* *} \\
(0.012)\end{array}$ & $\begin{array}{l}0.0394 \\
(0.071)\end{array}$ \\
\hline Profit Margin & $\begin{array}{c}0.2098^{*} \\
(0.107)\end{array}$ & $\begin{array}{c}0.9290 * * * \\
(0.025)\end{array}$ & & & & \\
\hline Asset Turnover & & & $\begin{array}{c}0.9967^{* * *} \\
(0.007)\end{array}$ & $\begin{array}{c}0.9571^{* * *} \\
(0.009)\end{array}$ & & \\
\hline Leverage & & & & & $\begin{array}{c}0.9688^{* * *} \\
(0.025)\end{array}$ & $\begin{array}{c}0.8435^{* * *} \\
(0.060)\end{array}$ \\
\hline Log Market Cap & $\begin{array}{c}-0.0034^{*} \\
(0.002)\end{array}$ & $\begin{array}{c}0.0087^{* * * *} \\
(0.002)\end{array}$ & $\begin{array}{c}0.0073^{* * *} \\
(0.002)\end{array}$ & $\begin{array}{c}0.0089^{* *} \\
(0.004)\end{array}$ & $\begin{array}{l}0.0057 \\
(0.006)\end{array}$ & $\begin{array}{c}0.1171^{* * *} \\
(0.036)\end{array}$ \\
\hline Book to Market & $\begin{array}{c}-0.0138^{* * *} \\
(0.004)\end{array}$ & $\begin{array}{c}-0.0178 * * * \\
(0.005)\end{array}$ & $\begin{array}{c}-0.0253^{* * *} \\
(0.005)\end{array}$ & $\begin{array}{l}-0.0109 \\
(0.011)\end{array}$ & $\begin{array}{c}-0.0345^{* *} \\
(0.017)\end{array}$ & $\begin{array}{c}0.3205^{* * *} \\
(0.087)\end{array}$ \\
\hline Sales Growth & $\begin{array}{r}-0.0058 \\
(0.013)\end{array}$ & $\begin{array}{c}-0.0322^{* *} \\
(0.015)\end{array}$ & $\begin{array}{r}-0.0370 \\
(0.026)\end{array}$ & $\begin{array}{c}-0.0375 \\
(0.044)\end{array}$ & $\begin{array}{r}-0.0506 \\
(0.036)\end{array}$ & $\begin{array}{c}-0.0793 \\
(0.231)\end{array}$ \\
\hline LT Debt to Equity & $\begin{array}{c}-0.0056^{* *} \\
(0.002)\end{array}$ & $\begin{array}{c}-0.0024 \\
(0.005)\end{array}$ & $\begin{array}{l}0.0010 \\
(0.003)\end{array}$ & $\begin{array}{l}0.0134 \\
(0.016)\end{array}$ & $\begin{array}{l}0.0379 \\
(0.046)\end{array}$ & $\begin{array}{c}0.3349^{* *} \\
(0.138)\end{array}$ \\
\hline Cash to Equity & $\begin{array}{l}0.0072 \\
(0.006)\end{array}$ & $\begin{array}{c}-0.0088^{*} \\
(0.005)\end{array}$ & $\begin{array}{l}0.0073 \\
(0.006)\end{array}$ & $\begin{array}{c}-0.0454^{*} \\
(0.024)\end{array}$ & $\begin{array}{c}-0.0634^{* *} \\
(0.030)\end{array}$ & $\begin{array}{l}0.2744 \\
(0.171)\end{array}$ \\
\hline Time FE & Yes & Yes & Yes & Yes & Yes & Yes \\
\hline Observations & 1,058 & 1,261 & 1,126 & 1,193 & 1,256 & 1,063 \\
\hline$R^{2}$ & 0.1125 & 0.7375 & 0.9323 & 0.9186 & 0.6836 & 0.8510 \\
\hline
\end{tabular}


Table 7.

Shareholder Payouts

Table 7 reports the results of DID regressions using Shareholder Payouts as the dependent variables, with year fixed effects, the same set of control variables, and the contemporaneous dependent variable included. As in the previous tables, Treat is equal to one for firms ranked 300-500 under the JPX400 selection algorithm and zero for firms ranked 500-800, while Post is an indicator variable assuming the value one for years 2014-2015, and zero for the pre-treatment period, i.e., 2010-2012. Column 1 reports results for the regression estimated on the full sample, while Columns 2 and 3 report separate results for firms with above-median vs. below-median contemporaneous cash-to-equity ratios. The starting sample for all analyses is one for which all variables used in the baseline analysis, i.e., columns (3) - (5) of Table 3, are available. All variables are defined in Table A1. Standard errors, clustered at the firm level, are reported in parentheses. Significance levels are indicated by ${ }^{*},{ }^{* *},{ }^{* *}$ for $10 \%, 5 \%$, and $1 \%$, respectively.

\begin{tabular}{lccc}
\hline \hline & $(1)$ & $(2)$ & $(3)$ \\
& All & $\begin{array}{c}\text { Below-Median } \\
\text { Cash-to-Equity }\end{array}$ & $\begin{array}{c}\text { Above-Median } \\
\text { Cash-to-Equity }\end{array}$ \\
\hline Treat x Post & $0.005^{* *}$ & 0.002 & $0.009^{* *}$ \\
Treat & $(0.00)$ & $(0.00)$ & $(0.00)$ \\
& $-0.003^{* * *}$ & -0.001 & $-0.007^{* * *}$ \\
Repurchases to Equity & $(0.00)$ & $(0.00)$ & $(0.00)$ \\
& 0.076 & $0.204^{* *}$ & 0.022 \\
Dividends to Equity & $(0.05)$ & $(0.09)$ & $(0.05)$ \\
& $0.898^{* * *}$ & $0.839^{* * *}$ & $0.913^{* * *}$ \\
Log Market Cap & $(0.06)$ & $(0.06)$ & $(0.09)$ \\
& 0.001 & 0.001 & 0.001 \\
Book to Market & $(0.00)$ & $(0.00)$ & $(0.00)$ \\
& $-0.006^{* * *}$ & $-0.006^{* * *}$ & $-0.007^{* * *}$ \\
Sales Growth & $(0.00)$ & $(0.00)$ & $0.00)$ \\
& 0.004 & 0.001 & 0.006 \\
LT Debt to Equity & $(0.00)$ & $(0.00)$ & $-0.01)$ \\
& $-0.002^{*}$ & $-0.002^{* * *}$ & $(0.00)$ \\
Cash to Equity & $(0.00)$ & $(0.00)$ & 0.006 \\
& $0.007^{* * *}$ & -0.002 & $(0.00)$ \\
\hline Time FE & $(0.00)$ & $(0.01)$ & Yes \\
Observations & Yes & Yes & 1,024 \\
$R^{2}$ & 2,317 & 1,293 & 0.2993 \\
\hline \hline
\end{tabular}


Table 8.

Investments and Accruals

Table 8 reports the results of DID regressions using alternative outcome variables - Forward Accruals to Assets, Forward Net Operating Assets, Forward REDD to Sales, and Forward Log Employees. As in Table 3 , Treat is equal to one for firms ranked 300-500 under the JPX400 selection algorithm and zero for firms ranked 500-800, while Post is an indicator variable assuming the value one for years 2014-2015, and zero for the pre-treatment period, i.e., 2010-2012. All specifications use the same controls and year fixed effects, and vary to include the contemporaneous version of the dependent variable as a control. The starting sample for all analyses is one for which all variables used in the baseline analysis, i.e., columns (3) - (5) of Table 3, are available. Observations vary across specifications depending on the availability of specific new variables used for the analysis. All variables are defined in Table A1. Standard errors, clustered at the firm level, are reported in parentheses. Significance levels are indicated by ${ }^{*},{ }^{* *},{ }^{* * *}$ for $10 \%, 5 \%$, and $1 \%$, respectively.

\begin{tabular}{|c|c|c|c|c|}
\hline & $\begin{array}{c}(1) \\
\text { Forward Accruals } \\
\text { to Assets }\end{array}$ & $\begin{array}{c}(2) \\
\text { Forward Log } \\
\text { NOA }\end{array}$ & $\begin{array}{c}(3) \\
\text { Forward R\&D } \\
\text { to Sales }\end{array}$ & $\begin{array}{c}(4) \\
\text { Forward Log } \\
\text { Employees }\end{array}$ \\
\hline Treat $\mathrm{x}$ Post & $\begin{array}{l}0.001 \\
(0.00)\end{array}$ & $\begin{array}{l}0.011 \\
(0.02)\end{array}$ & $\begin{array}{l}-0.000 \\
(0.00)\end{array}$ & $\begin{array}{l}-0.002 \\
(0.01)\end{array}$ \\
\hline Treat & $\begin{array}{l}0.001 \\
(0.00)\end{array}$ & $\begin{array}{l}0.010 \\
(0.01)\end{array}$ & $\begin{array}{c}0.001^{* * *} \\
(0.00)\end{array}$ & $\begin{array}{l}0.002 \\
(0.01)\end{array}$ \\
\hline Accruals to Assets & $\begin{array}{c}0.455^{* * *} \\
(0.03)\end{array}$ & & & \\
\hline $\log N O A$ & & $\begin{array}{c}0.801^{* * *} \\
(0.05)\end{array}$ & & \\
\hline RED to Sales & & & $\begin{array}{c}0.986^{* * *} \\
(0.01)\end{array}$ & \\
\hline Log Employees & & & & $\begin{array}{c}0.996^{* * *} \\
(0.00)\end{array}$ \\
\hline Log Market Cap & $\begin{array}{l}-0.001 \\
(0.00)\end{array}$ & $\begin{array}{c}0.186^{* * *} \\
(0.05)\end{array}$ & $\begin{array}{c}-0.000^{* *} \\
(0.00)\end{array}$ & $\begin{array}{l}-0.006 \\
(0.00)\end{array}$ \\
\hline Book to Market & $\begin{array}{c}0.005^{* * *} \\
(0.00)\end{array}$ & $\begin{array}{c}0.205^{* * *} \\
(0.06)\end{array}$ & $\begin{array}{c}0.001^{* *} \\
(0.00)\end{array}$ & $\begin{array}{c}-0.029^{* * *} \\
(0.01)\end{array}$ \\
\hline Sales Growth & $\begin{array}{c}0.029^{* * *} \\
(0.01)\end{array}$ & $\begin{array}{c}0.170^{* * *} \\
(0.06)\end{array}$ & $\begin{array}{c}0.003^{* *} \\
(0.00)\end{array}$ & $\begin{array}{c}0.074^{* * *} \\
(0.02)\end{array}$ \\
\hline LT Debt to Equity & $\begin{array}{l}-0.001 \\
(0.00)\end{array}$ & $\begin{array}{c}0.111^{* * * *} \\
(0.04)\end{array}$ & $\begin{array}{l}0.000 \\
(0.00)\end{array}$ & $\begin{array}{l}0.004 \\
(0.01)\end{array}$ \\
\hline Cash to Equity & $\begin{array}{c}0.012^{* * *} \\
(0.00)\end{array}$ & $\begin{array}{c}-0.105^{*} \\
(0.06)\end{array}$ & $\begin{array}{l}0.001 \\
(0.00) \\
\end{array}$ & $\begin{array}{l}-0.011 \\
(0.01)\end{array}$ \\
\hline Time FE & Yes & Yes & Yes & Yes \\
\hline Observations & 2,313 & 2,256 & 2,320 & 2,208 \\
\hline$R^{2}$ & 0.2764 & 0.9635 & 0.9491 & 0.9906 \\
\hline
\end{tabular}




\section{Table 9.}

\section{Market Valuation}

Table 9 reports the results of instrumental variables analyses using Forward BM, i.e., one-year ahead book-to-market ratio as the outcome variable. Here our endogenous variable of interest is one-year ahead return on equity, Forward ROE, which is instrumented for by our main differences-in-differences estimator, Treat $\mathrm{x}$ Post. As in earlier analyses, Treat is equal to one for firms ranked 300-500 under the JPX400 selection algorithm and zero for firms ranked 500-800, while Post is an indicator variable assuming the value one for years 2014-2015, and zero for the pre-treatment period, i.e., 2010-2012. All specifications use the same controls and year fixed effects. Column (1) reports the results of a reduced form version of the IV, which translates into a specification similar to our main DID specification used in column (4) of Table 3, but with Forward BM as the outcome variable. Columns (2) and (3) report the first and second stages of a 2SLS regression and thus the coefficient of interest is that on Forward ROE in column (3). The last row of column (2) reports the first-stage F-statistic of a test for weak instruments. Standard errors, clustered at the firm level, are reported in parantheses. Significance levels are indicated by ${ }^{*},{ }^{* *},{ }^{* * *}$ for $10 \%, 5 \%$, and $1 \%$, respectively.

\begin{tabular}{|c|c|c|c|}
\hline & $\begin{array}{l}\text { (1) } \\
\text { OLS }\end{array}$ & $\begin{array}{c}(2) \\
\text { IV } 1^{\text {st }} \text { Stage }\end{array}$ & $\begin{array}{c}(3) \\
\text { IV } 2^{\text {nd }} \text { Stage }\end{array}$ \\
\hline & Forward Book to Market & Forward ROE & Forward Book to Market \\
\hline Forward ROE & & & $\begin{array}{c}-2.327^{*} \\
(1.41)\end{array}$ \\
\hline Treat $\mathrm{x}$ Post & $\begin{array}{c}-0.043^{*} \\
(0.02)\end{array}$ & $\begin{array}{c}0.019^{* * *} \\
(0.01)\end{array}$ & \\
\hline Treat & $\begin{array}{l}0.010 \\
(0.02)\end{array}$ & $\begin{array}{c}-0.008^{*} \\
(0.00)\end{array}$ & $\begin{array}{r}-0.008 \\
(0.02)\end{array}$ \\
\hline$R O E$ & $\begin{array}{c}0.250^{* *} \\
(0.12)\end{array}$ & $\begin{array}{c}0.516^{* * *} \\
(0.07)\end{array}$ & $\begin{array}{c}1.452^{* *} \\
(0.74)\end{array}$ \\
\hline Log Market Cap & $\begin{array}{c}-0.016^{*} \\
(0.01)\end{array}$ & $\begin{array}{c}-0.007^{* *} \\
(0.00)\end{array}$ & $\begin{array}{c}-0.033^{* *} \\
(0.02)\end{array}$ \\
\hline Book to Market & $\begin{array}{c}0.903^{* * *} \\
(0.02)\end{array}$ & $\begin{array}{c}-0.043^{* * *} \\
(0.01)\end{array}$ & $\begin{array}{c}0.804^{* * *} \\
(0.06)\end{array}$ \\
\hline Sales Growth & $\begin{array}{c}0.188^{* * *} \\
(0.05)\end{array}$ & $\begin{array}{r}-0.018 \\
(0.02)\end{array}$ & $\begin{array}{c}0.146^{* *} \\
(0.07)\end{array}$ \\
\hline LT Debt to Equity & $\begin{array}{c}-0.025^{* * *} \\
(0.01)\end{array}$ & $\begin{array}{c}-0.010^{* *} \\
(0.00)\end{array}$ & $\begin{array}{c}-0.048^{* *} \\
(0.02)\end{array}$ \\
\hline Cash to Equity & $\begin{array}{c}-0.055^{* *} \\
(0.02) \\
\end{array}$ & $\begin{array}{l}0.002 \\
(0.01) \\
\end{array}$ & $\begin{array}{c}-0.051^{* *} \\
(0.02)\end{array}$ \\
\hline Time FE & Yes & Yes & Yes \\
\hline Observations & 2,311 & 2,311 & 2,311 \\
\hline$R^{2}$ & 0.7181 & 0.3924 & 0.6498 \\
\hline First Stage $F$ & & 9.5343 & \\
\hline
\end{tabular}

